10-2019

\title{
Financial crises and the asymmetric relation between returns on banks, risk factors, and other industry portfolio returns
}

Kenneth Högholm

Johan Knif

Gregory Koutmos

Seppo Pynnönen

Follow this and additional works at: https://digitalcommons.fairfield.edu/business-facultypubs (C) 2019 The Eastern Finance Association

This is the peer reviewed version of the following article: Högholm, Kenneth, Johan Knif, Gregory Koutmos, and Seppo Pynnönen. "Financial crises and the asymmetric relation between returns on banks, risk factors, and other industry portfolio returns." Financial Review, which has been published in final form at https://doi.org/10.1111/fire.12214. This article may be used for noncommercial purposes in accordance with Wiley Terms and Conditions for Use of Self-Archived Versions.

\section{Peer Reviewed}

\section{Published Citation}

Högholm, Kenneth, Johan Knif, Gregory Koutmos, and Seppo Pynnönen. "Financial crises and the asymmetric relation between returns on banks, risk factors, and other industry portfolio returns." Financial Review. doi: 10.1111/ fire. 12214

This item has been accepted for inclusion in DigitalCommons@Fairfield by an authorized administrator of DigitalCommons@Fairfield. It is brought to you by DigitalCommons@Fairfield with permission from the rightsholder(s) and is protected by copyright and/or related rights. You are free to use this item in any way that is permitted by the copyright and related rights legislation that applies to your use. For other uses, you need to obtain permission from the rights-holder(s) directly, unless additional rights are indicated by a Creative Commons license in the record and/or on the work itself. For more information, please contact digitalcommons@fairfield.edu. 
Published in the Financial Review, Dol: 10.1111/fire.12214

\title{
Financial crises and the asymmetric relation between returns on banks, risk factors, and other industry portfolio returns
}

\author{
Kenneth Högholm ${ }^{1}$ \\ Johan Knif ${ }^{2}$ \\ Gregory Koutmos ${ }^{3}$ \\ Seppo Pynnönen ${ }^{4}$ \\ February 25, 2019
}

\begin{abstract}
The study analyzes monthly returns on 48 US industry portfolios and six risk factors over the period from January 1970 to February 2017 to show that the dynamic linkages between the returns on the banking industry portfolio, risk factors, and other industries often are asymmetric in two ways. First, the results show a one-directional causality running from the banking industry to several other industries but seldom the other way around. Lagged banking industry returns improve predictability of returns on several other industry portfolios. For many industry portfolios, returns on the banking portfolio can be regarded as exogenous and seem to Granger cause other industry returns. Second, the cross-autocorrelation appears to be asymmetric in a sense that on average the impact of a one-month lag of the return on the banking portfolio is much higher in the lower part of the conditional return distribution than in the upper part. This indicates that the dynamic relationship is both endogenous and time varying. The results are robust over several crises sub-periods. However, after the implementation of the Dodd-Frank Wall Street Reform and Consumer Protection Act in 2010 the cross-autocorrelation asymmetry with banking industry returns is changed and becomes negative, especially in the positive part of the conditional industry return distribution. Finally, returns on the banking industry portfolio seem to Granger cause and lead the returns on the market, size, value, momentum, and investment factors. This relation is, however, not robust across the return distribution.

\footnotetext{
${ }^{1}$ Department of Finance and Statistics, Hanken School of Economics, P.O. Box 287, FIN-65101 Vaasa, Finland, kenneth.hogholm@hanken.fi

${ }^{2}$ Department of Finance and Statistics, Hanken School of Economics, P.O. Box 287, FIN-65101 Vaasa, Finland, johan.knif@hanken.fi,
} 
3Department of Finance, Charles F. Dolan School of Business, Fairfield University, CT, 06430, USA, gkoutmos@ fairfield.edu, corresponding author

${ }^{4}$ Department of Statistics, University of Vaasa, P.O. Box 700, FIN-65101 Vaasa, Finland, seppo.pynnönen@uwasa.fi

Acknowledgements: Financial support from the Hanken Support Foundation is highly appreciated. 


\section{Introduction}

Following and developing the approach of Högholm, Knif, and Koutmos (2014), this paper studies the dynamic linkages between returns on industry portfolios by specifically focusing on the asymmetric role of the banking industry in the dynamic linkages among industry portfolio returns and risk factors. Using monthly returns on 48 US industry portfolios and six risk factors, the results suggest that the dynamic linkages between the returns on the banking industry portfolio and other industries often are asymmetric in two ways. First, there is a one-directional causality relation running from the banking industry to several other industries but seldom the other way around. One-month lagged banking industry returns seem to improve predictability of returns on several industry portfolios. The returns on the banking portfolio also seem to improve predictability of the size, value, momentum, and investment factors. Furthermore, for many industry portfolios, returns on the banking industry portfolio can be regarded as exogenous and seem to Granger cause other industry returns. Second, the cross-autocorrelation structure is found to be asymmetric in a sense that on average the impact of a one-month lag of the return on the banking portfolio is much higher in the lower part of the conditional return distribution than in the upper part. These results are robust over several crises sub-periods. However, after the implementation of the Dodd-Frank Wall Street Reform and Consumer Protection Act in 2010 the autocorrelation asymmetry is changed and becomes negative, especially in the upper part of the conditional industry return distribution. It is also found that returns on the banking industry portfolio seem to be dynamically connected to five of the six classic asset-pricing risk factors. These are the market, size, value, momentum, and investment risk factors. However, this dynamic relationship is not robust across the return distribution and can hence be regarded as endogenous.

Due to differences in exposures to risk factors, it is expected that in some market situations the returns on one industry portfolio could lead or lag the returns on some other industry portfolios with different risk exposure characteristics. However, the source of the empirically observed lead-lag effects is still a subject of debate. The literature proposes five main explanations for this phenomenon: non-synchronous trading (e.g. Lo and MacKinley (1990a)), time-varying expected returns (e.g. Hameed (1997)), asymmetric information (e.g. Zebedee and 
Kasch-Haroutounian (2009), imperfect information (Chan (1993)), and slow diffusion of information (Merton (1987) and Lo and MacKinley (1990b)).

Using a static model of multiple stocks where investors have access to limited information, Merton (1987) shows that stocks with a smaller investor base are traded at greater discount due to limited risk sharing. Merton (1987) also suggests that market segmentation and limited participation could be a reason for slowness of investors in one market to absorb information from another market. This argument is often called the gradual-informationdiffusion hypothesis. Hou (2007) found that this slow diffusion of information is the leading cause of the lead-lag effect and that it is predominantly an intra-industry phenomenon that is associated with firm size: big firms lead small firms. This explanation is also provided by Ayers and Freeman (2000) and thoroughly examined across industries by Cen, Chan, Dasgupta, and Gao (2013). Anderson, Eom, Hahn and Park (2013) find compelling evidence that this partial price adjustment is a major source of the autocorrelation in returns.

Hong, Torous, and Valkanov (2007) also find that the gradual-information-diffusion hypothesis provides a key auxiliary explanation for the lead-lag relations but might not be the only one. Using monthly returns on 34 value-weighted US industry portfolios over the period from 1946 to 2001 they found that 14 industries were able to predict market movements by one month. A few industries such as petroleum, metal, and financial could predict the market up to two months ahead. They also provided remarkably similar empirical evidence for the eight largest non-US equity markets. Their conclusion is that stock markets as a whole might react with a delay to fundamental information contained in industry returns and that information diffuses only gradually across markets. On the other hand, Tse (2015) only documents one to seven industries out of 34 having predictive ability of stock market movements.

Laopodis (2016) continues on this issue and empirically investigates the dynamic linkages among industries and the stock market. Using a newer dataset based on monthly returns on seventeen large US industry portfolios and the aggregate stock market over the period from 1957 to 2013, he finds that certain industries provide strong predictive ability both to the aggregate market and many other industries. Examining the dynamic behavior over bull and bear markets separately he finds no consistent patterns of responses.

Chan (1993) and McQueen, Pinegar, and Thorley (1996) find directional asymmetry in the small stock response to large stock movements. International evidence is presented in e.g. 
Altay (2004) for the German and Turkish markets. Doong, Yang, and Chiang (2005) and Lee, Chen, and Chang (2013) present results for the Asian stock markets.

However, Bernhardt and Mahani (2007) argued that information asymmetry cannot fully explain asymmetry in lead-lag relations. Additional frictions are necessary to produce asymmetry in cross-autocorrelations of stock returns. Furthermore, the results of Chou, Ho, and Ko (2013) indicate that common risk factors extracted from industry returns contain significant risk premiums and have explanatory power up and above those of size, value and momentum.

Baur, Dimpfl, and Jung (2012) recognize another type of asymmetry of return autocorrelations. They analyze the dependence pattern over a range of quantiles of the conditional return distribution. The results indicate positive dependence on past returns in the lower part of the distribution while the upper quantiles are marked by negative serial dependence. This type of dependence on the outcome of the conditional distribution will make the autocorrelation structure at least partly endogenous and hence empirically time-varying. The time-varying characteristic of the cross-autocorrelation structure is also investigated in Kinnunen (2013).

The special systemic role of the banking industry has been recognized for a long time. The credit channel effect has been thoroughly discussed by Bernanke (1993), Bernanke and Gertler (1995), and Anari, Kolari, and Mason (2004). Furthermore, using monthly US stock returns and Markov-switching models, Chen (2007) shows that monetary policy has an asymmetric effect on returns with a pronounced effect during bear markets. In a more recent paper Hammami and Lindahl (2014) report empirical findings that underscore the relevance of bank credit growth for stock prices. They conclude that bank credit growth is important because it is able to predict business cycle variables and labor income growth.

This study focuses specifically on the role of the banking industry in the dynamic leadlag relation to other industries. The banking industry is sensitive to economic crises as well as to monetary policy changes and to changes in regulations. Furthermore, as the banking industry by its liquidity providing nature is closely related to all other industries, it is expected that the banking sector plays a major role in the dynamic interdependencies. On the one hand, the banks are dependent on the performance of other industries. On the other hand, other industries are financially dependent of the performance of the banking sector. Indeed, as Gorton and Winton (2002) show, banks account for nearly $25 \%$ of external capital provided to firms. 
The empirical results of this study indicate a dynamic linkage between the returns on the banking portfolio and other industry portfolios that appears to be asymmetric in two ways. First, a one-directional causality relation running from the banking industry to several other industries is found but seldom the other way around. Lagged banking industry returns seem to improve the predictability of returns for several industry portfolios. Surprisingly, for many industry portfolios returns on the banking industry portfolio can be regarded as exogenous and Granger causes other industry returns. Second, in line with Chen (2007) and Baur et al. (2012) the results show asymmetry in the autocorrelation structure: positive in the lower part of the conditional return distribution and negative in the upper part.

The purpose of the Frank-Dodd Act of July 2010 was to decrease the risk of the effects of crises in the financial sector by enforcing transparency and accountability and places the regulation of the financial industry in the hands of the government.

In times of crises, companies in different industries experience shortage of funding from internal untied equity and the possibility for successful new share issues are limited. The dependence on the banking industry to provide funding is hence expected to be more pronounced during periods of crises. This would indicate a positive cross-autocorrelation. During non-crises periods the expectation is the opposite as companies have untied equity available and opportunities for issuing new equity exists. As a consequence it might be harder for the banking industry to increase earnings on loaning activities during non-crises periods. This would indicate a negative cross-autocorrelation with the banking industry.

The empirical results indicate that with the Dodd-Frank Act of August 2010 the dynamic linkages between returns on the banking industry and other industry portfolios changes. Before the implementation the Granger causality from the banking industry was especially high. However, after the implementation of the Dodd-Frank Act this Granger causality almost disappears. The results for the conditional cross-autocorrelation with the banking industry is similar. Before the implementation this cross-autocorrelation is very high and positive whereas it is lower and becomes negative in the post implementation subsample.

The rest of the study is structured as follows. Section 2 describes the empirical methodology applied. Section 3 presents the data and industry classifications. Section 4 reports the empirical findings and Section 5 summarizes and concludes. 


\section{Methodology}

In order to monitor the role of the banking industry in the dynamic linkages with other industries, we first investigate the individual unconditional autocorrelation structure for each industry separately. Traditionally the autocorrelation as a function of the lag-length $k$ is calculated as $\rho(k)=\gamma(k) / \gamma(0)$, where $\gamma$ is the auto-covariance function, $\gamma(k)=\operatorname{cov}\left(r_{t}^{i n d}, r_{t-k}^{\text {ind }}\right)$, and $r_{t}^{\text {ind }}$ is the continuously compounded return on the industry index for time period $t$.

Following the VAR approach applied by Laopodis (2016), we study the Granger causality between the banking industry and the other industries. The basic VAR-model with two lags for this analysis is

$$
\begin{gathered}
r_{t}^{\text {banks }}=\beta_{10}+\beta_{11} r_{t-1}^{\text {banks }}+\beta_{12} r_{t-2}^{\text {banks }}+\beta_{13} r_{t-1}^{\text {ind }}+\beta_{14} r_{t-2}^{\text {ind }}+\varepsilon_{t}^{\text {banks }} \\
r_{t}^{\text {ind }}=\beta_{20}+\beta_{21} r_{t-1}^{\text {ind }}+\beta_{22} r_{t-2}^{\text {ind }}+\beta_{23} r_{t-1}^{\text {banks }}+\beta_{24} r_{t-2}^{\text {banks }}+\varepsilon_{t}^{\text {ind }} .
\end{gathered}
$$

The two null hypotheses in the Granger casualty test are that returns on the industry portfolio (ind) do not Granger cause returns on the banking industry portfolio (banks), $\beta_{13}=$ $\beta_{14}=0$, and that returns on the banking industry portfolio (banks) do not Granger cause returns on the industry portfolio (ind), $\beta_{23}=\beta_{24}=0$.

As a basic benchmark we estimate a model to monitor the impact of lagged information from the banking industry on other industries. The following model is estimated using OLS:

$$
r_{t}^{\text {ind }}=\beta_{0}+\beta_{1} r_{t-1}^{\text {ind }}+\beta_{2} r_{t-1}^{\text {banks }}+\varepsilon_{t}^{\text {ind }}
$$

We develop the modeling further by estimating the basic model using quantile regression. In line with Baur, Dimpfl, and Jung (2012), we check this model for robustness over the conditional return distribution using the quantile regression approach of Koenker and Bassett (1978). This approach is described in detail in Koenker (2005). The traditional regression approach (OLS) focuses on the conditional mean of the dependent variable and implicitly assumes that this is a good representation for the entire distribution. The quantile regression 
approach, on the other hand, models the regression relationship over different quantiles of the conditional distribution of the dependent variable given conditioning explanatory variables. This enables monitoring and testing of the regression coefficients across different parts of the conditional return distribution. Furthermore, as quantile regression requires weaker distributional assumptions, it provides a more robust method of modeling the conditional return distribution and is, hence, less sensitive to extreme observations. Traditional quantile estimators provide conditional estimates of the lead-lag structure. These estimates are, on the one hand, by definition conditional on the lag specifications in the estimated model. On the other hand, the quantile estimates are also conditional upon the quantile parameter that specifies the weighting across the distribution of the idiosyncratic component.

The quantile regression approach is also applied to empirical finance in Högholm, Knif, and Pynnönen (2011a,b) and Högholm, Knif, Koutmos, and Pynnönen (2011). Using the conditional quantile regression, explicit conditioning state variables do not need to be specified as the estimation procedure implicitly accounts for the joint effect of possible state variables by conditioning on the residual distribution. For the quantile regression analysis, equation (2) is rewritten in the form

$$
r_{t}^{\text {ind }}=\beta_{0}(\tau)+\beta_{1}(\tau) r_{t-1}^{\text {ind }}+\beta_{2}(\tau) r_{t-1}^{\text {banks }}+\varepsilon_{t}^{i n d}
$$

where $\beta_{i}(\tau), i=0,1,2$, will be functions of the quantile parameter $\tau$. The quantile regression will solve the minimization problem

$$
\min _{\beta_{i}(\tau), i=0,1,2}\left[\sum_{t: r_{t}^{i n d} \geq \hat{r}_{t}^{i n d}} \tau\left|r_{t}^{i n d}-\hat{r}_{t}^{\text {ind }}\right|+\sum_{t: r_{t}^{\text {ind }}<\hat{r}_{t}^{\text {ind }}}(1-\tau)\left|r_{t}^{\text {ind }}-\hat{r}_{t}^{\text {ind }}\right|\right]
$$

where $\hat{r}_{t}^{\text {ind }}$ is the estimated expectation of (3) and $\tau$ is the quantile parameter ranging from 0 to 1. In case of $\tau=1$, the quantile regression will result in a least-absolute-deviation regression for positive residuals. Correspondingly, in case $\tau=0$, the result is a least-absolute-deviation regression for negative residuals. Setting $\tau=0.5$ provides a least-absolute-deviation regression at the median. Letting $\tau$ vary between 0 and 1 , the quantile regression will monitor the regression lead-lag relationship across the entire conditional industry return distribution. As $\tau$ defines the weighting pattern over the conditional return distribution for the minimization in (4), the quantile 
regression will estimate a model that is implicitly non-linear with implicitly time-varying and conditional regression coefficients. A corresponding quantile regression is used for the study of the dynamic relation between risk factors and returns on the banking industry portfolio. In these regressions the industry return is replaced by the return on the risk factor.

\section{Data}

The sample data used in the empirical estimation and testing consists of monthly returns on 48 US value-weighted industry portfolios over the period from January 1970 to February 2017. The sample period is also analyzed over subsamples. The sample period covers the Oil Crisis in early 1970:s, the Latin Americas Sovereign Debt Crisis in 1982, the Savings and Loan Crises of the 1980:s and the Financial Institutions Reform, Recovery and Enforcement Act in 1989, the Stock Market Crash (Black Monday) in 1987, the Junk Bond Crash in 1989, the Tequila Crash in 1994, the Asian Crisis in 1997-1998, the Dot.Com bubble in 1999-2000, and the Global Financial Crisis 2007-2008. We focus on mainly two sub-samples. These are the periods before and after the implementation of the Dodd-Frank Wall Street Reform and Consumer Protection Act in August 2010. The sub-samples are chosen with similar sample-period lengths in order to have comparable degrees of freedom between sub-samples. This will make a comparison of the number of statistical significances possible. The two sub-samples are January 2004 to July 2010 and August 2010 to February 2017. Results for the other sub periods are available on request.

The data for the industry portfolios and the risk factors is downloaded from Kenneth French data library (http://mba.tuck.dartmouth.edu/pages/faculty/ken.french/data_library.html). According to this industry classification structure, the banking industry portfolio contains equity from the sectors listed in Table 1 and the other 47 industries are presented in Appendix A. As seen from this industry classification, all borrowing and lending activities are grouped in the banking industry whereas all financial trading is concentrated to the finance and trading industry, and all insurance activities are grouped in the insurance industry.

\section{[Insert Table 1]}

The risk factors chosen are those presented by Fama and French $(1993,2015)$ and by Carhart (1997) including the market risk factor, the size factor, the value factor, the momentum 
factor, the investment factor, and the profitability factor. A detailed description of these risk factors can be found in Kenneth French data library.

Table 2 summarizes the descriptive statistics of the return distributions for the 48 individual industry indexes for the total sample period. The mean monthly return on all industry portfolios is positive. The highest monthly mean return of $1.49 \%$ is measured for the tobaccoproduct industry (smoke) and the lowest mean return of $0.55 \%$ for the industry group "other". This "other" industry group contains e.g. sanitary services, steam, air conditioning supplies, and irrigation systems. The standard deviation is highest, 10.97, for the coal (coal) and the precious metal industry (gold) and lowest, 4.10, for utilities industry (util). The skewness is negative for the majority of the industry return distributions but positive and relatively high for the precious metal industry (gold). All industry portfolios exhibit excess kurtosis and this is especially high for the textiles industry (txtls). The Jarque-Bera statistic does not support the assumption that the unconditional industry return distributions are symmetric with no excess kurtosis.

\section{[Insert Table 2]}

Table 3 presents descriptive statistics for the return distribution for the risk factors over the total sample period. The mean return for all six risk factors are positive for the sample period. Returns on market, momentum, and profitability factors are negatively skewed with a very high kurtosis for momentum and profitability. As for the industry returns the Jarque-Bera statistic does not support the assumption that the unconditional factor return distributions are symmetric with no excess kurtosis.

\section{[Insert Table 3]}

Table 4 presents the first two partial autocorrelation coefficients for the returns on the industry portfolios. For the total sample period all the 27 (out of 48) statistically significant autoregression coefficients are positive and especially high, 0.211 , for the real estate industry (rlest). The banking industry (banks) has a first order partial autocorrelation coefficient of 0.114 . The second order partial correlation is on average lower and negative for the majority of the industries. One exception is the coal industry (coal) with a positive second order partial autocorrelation coefficient. For the financial crisis sub period before the Dodd-Frank Act, January 2004 to July 2010, only four of the first order autocorrelation coefficients are statistically significant. On the other hand, these are in absolute value high. For the banking 
industry (banks) 0.314, for the real estate industry (rlest) the coefficient is also positive and as high as 0.445 and for the textiles industry (txtls) correspondingly 0.302 . For the precious metal industry (gold) the coefficient is negative, -0.205 . For this sub period there are only three statistically significant second order partial autocorrelations, -0.206 for the banking industry (banks), -0.221 for the apparel industry (clths), and -0.195 for the recreation industry (toys). The partial autocorrelation structure for the period after the Dodd-Frank Act, August 2010 to February 2017 is different. All of the 9 (out of 48) statistically significant correlations are negative and there seems to be no second order partial autocorrelations with one exception, the coal industry (coal) again.

\section{[Insert Table 4]}

The corresponding partial autocorrelation structure for the risk factors are presented in Table 5. For the total sample period the first order partial autocorrelation coefficients are positive and statistically significant for all factors except for size. No significant correlation structure is found for lag two for this period. For the sub period before the Dodd-Frank Act there are high, significant, and positive autocorrelations for market, value, and momentum. The second order autocorrelation coefficients are significant and negative for market and value. Again the autocorrelation structure is different for the sub period after the Dodd-Frank Act. There are only two significant first order autocorrelation coefficients, -0.273 for size and 0.220 for value and non for the second lag.

[Insert Table 5]

\section{Empirical Results}

In order to save space the empirical results are only reported for the total sample January 1970 to February 2017 and for the two subsamples before and after the introduction of the Dodd-Frank Wall Street Reform and Consumer Protection Act, that is January 2004 to July 2010 and August 2010 to February 2017 respectively. Results for the other sub periods are available on request. 


\subsection{VAR-based bivariate Granger causality tests}

Table 6 presents the results for the Granger causality tests with two lags. For the total sample period the null hypothesis that the banking industry does not Granger cause the industry is rejected for 24 out of 47 industries at the $10 \%$ level of significance or lower. On the other hand, there appears to be only one other industry that significantly Granger cause returns on the banking industry portfolio. This is the coal industry (coal). This indicates that for the 24 industries that are Granger caused by the banking industry the banking industry returns can be regarded as exogenous. Only the coal industry (coal) can be regarded as exogenous for the banking industry. Note that the bituminous coal industry (coal) portfolio did not exhibit any first order autocorrelation structure in Table 4 but a significant partial autocorrelation for a twomonth lag. Note that the F-statistics for Granger causality by banking industry are especially high for fabricated products (fabpr), real estate (rlest), and rubber and plastic products (rubbr).

For the financial crisis sub period, January 2004 to July 2010, the influence of the banking industry returns is striking. For 39 out of 47 industries the null hypothesis is rejected and indicates a one-directional Granger causality from banking returns to the other industry. The corresponding F-statistics are very high for chemicals (chems), fabricated products (fabpr), defense (guns), real estate (rlest), and textiles (txtls). On the other hand, there is no indication that another industries should Granger cause returns on the banking portfolio for this sub period.

For the sub period after the Dodd-Frank Act, August 2010 to February 2017 the situation has changed. Now the banking returns seem to Granger cause only 12 out of 47 other industries. On the other hand, 11 out of 47 other industries seem to Granger cause returns on the banking portfolio. Interestingly, the coal industry (coal) is not one of them. For this sub period the Fstatistics are overall also much more moderate. For 8 of the industries there seem to exist a bidirectional causality with the banking industry portfolio.

[Insert Table 6]

Granger causality with the traditional asset pricing risk factors is presented in Table 7. For the total sample period there is a strong indication of a one-directional Granger causality running from the banking industry to size, momentum, and profitability factors. The F-statistic is 
very high for the size factor. For the pre Dodd-Frank Act period the banking portfolio Granger causes market, size, and momentum. There also appears to be bi-directional causality with momentum and the profitability factor seem to Granger cause the banking industry. For the post Dodd-Frank Act period the situation is again changed. The banking portfolio only Granger causes the momentum factor whereas the investment factor appears to Granger cause the banking portfolio.

These results of Table 6 and 7 indicate that the total market, a weighted average of the industries, and the market risk factor was sensitive to change in returns on the banking industry before the Dodd-Frank Act but not in the period after.

[Insert Table 7]

\subsection{Cross-autocorrelation analysis}

In order to further investigate the impact of the cross-autocorrelation between the banking industry and the other industries, we run an OLS regression of the benchmark model (2) with HAC corrected standard deviations. The parameter estimates of the model are presented in Table 8 for the industry portfolios. For the total sample period the results indicate that for many of the industries the observed autocorrelation structure in Table 4 is in fact driven by the crossautocorrelation with the banking industry. When a one-month lag of the banking industry portfolio return is included in the model, the significance of the first order autocorrelation is lost for 11 of the 27 industries with significant first order autocorrelation coefficients. Only for the printing and publishing industry (books), the apparel industry (clts), financial trading (fin), entertainment (fun), healthcare industry (hlth), the restaurants, hotels, and motels industry (meals), the business-supply industry (paper), and the retail industry (rtail), the significance of the own autocorrelation structure remains. The impact of the cross-autocorrelation with the banking industry is positive and with coefficients as high as 0.267 for the real estate industry (rlest).

For the financial crisis sub period, January 2004 to July 2010, there are only three significant autocorrelations, these are for the agriculture (agric), coal (coal), and financial trading (fin) industries. The impact of the cross-autocorrelation with the banking industry is, on the other hand, more striking. For 28 out of 47 industries the first order cross-autoregression coefficients 
with the returns on the banking portfolio is positive and statistically significant. For the real estate industry (rlest) and the textiles industry (txtls) it is as high as 0.707 and 0.786 , respectively.

For the sub period after the Dodd-Frank Act there seem to be no cross-autocorrelation with banks anymore. The only exception is the automobiles and trucks industry (autos) with a significant negative first order cross-autoregression coefficient of -0.438. Significant negative first order autocorrelation is found for agriculture (agric), tobacco products (smoke), and utilities (util) and significant positive for transportation (trans).

\section{[Insert Table 8]}

Table 9 presents the corresponding benchmark cross-autoregression results for the six risk factors. For the total sample period the significance of the first order autocorrelation coefficient for the market factor is lost as a one-month lag of the banking industry is included in the regression even though this cross autocorrelation is not statistically significant at the $10 \%$ level (p-value is 0.146). The autocorrelation for value, investment, and profitability factors remain even if cross autocorrelation with banking industry is included. However, for the momentum factor the autocorrelation seems to me driven partly by the banking industry. The significant and positive cross-autocorrelation for size is lost after the Dodd-Frank Act and is replaced by a more significant negative first order autocorrelation.

These cross-autocorrelation results are in line with the results of the Granger causality tests. The connection between lagged banking portfolio returns and returns on other industry portfolios and risk factors are lost after the Dodd-Frank Act of August 2010.

\section{[Insert Table 9]}

Table 10 presents the quantile regression estimates of the autoregression coefficient $\beta_{1}(\tau)$ of model (3). For none of the industries is the autocorrelation coefficient statistically significant across the entire conditional distribution (i.e. for all values of the quantile parameter $\tau)$. For the majority of the industry portfolios, the significant autocorrelation appears either in the lower or upper part of the distribution. In all significant cases, except for the business supply 
industry (paper), the autocorrelation is positive in the lower part of the distribution. On the other hand, for many industry portfolios, the autocorrelation is negative in the upper part of the conditional distribution. These empirical results are in line with those of Baur et al. (2012). These results also indicate that on average, using OLS regression, the conditional autocorrelation structure would in many cases not be statistically significant as was shown in the first column of Table 8 .

[Insert Table 10]

The corresponding quantile regression estimates for the cross-autocorrelation coefficient $\beta_{2}(\tau)$ with the banking industry is presented in Table 11 . These results can be compared to the estimates in the second column of Table 8 . The significance of the positive cross-autocorrelation with the banking industry returns seem to be, in most cases, driven by the positive crossautocorrelation in the lower part of the conditional return distribution, $\tau<0.5$, more negative returns than expected. There is less evidence of cross-autocorrelation with banks in the upper part of the conditional distribution. Here some of the significant coefficients are also negative in the extreme upper tail of the distribution. In the extreme lower tail of the conditional return distribution the cross-autoregression coefficient is as high as 0.420 for the real estate industry portfolio (rlest) and also high for construction materials (bldmt), construction (cnstr), fabricated products (fabpr), and the rubber and plastic products (rubbr) industries. Only for the real estate industry (rlest) the cross -autocorrelation is high and robust across the entire conditional distribution. The asymmetric characteristic of the cross-autocorrelation indicates that the coefficient is both state dependent and time-varying.

[Insert Table 11]

Table 12 presents the corresponding quantile regressions for the risk factors.

$$
r_{t}^{\text {factor }}=\beta_{0}(\tau)+\beta_{1}(\tau) r_{t-1}^{\text {factor }}+\beta_{2}(\tau) r_{t-1}^{\text {banks }}+\varepsilon_{t}^{\text {factor }}
$$


The first panel shows the estimates of the autocorrelation and the second panel shows the estimates of the cross-autocorrelation with the banking industry. The size and momentum factors exhibit no autocorrelation structure. For value, investment, and profitability factors the autocorrelation is positive and higher in the upper tail of the distribution. The market factor is positively autocorrelated only in the extreme negative tail of the distribution.

All risk factors except profitability are cross-autocorrelated with returns on the banking industry at least in some part of the return distribution. Only the size factor seems to have a robust positive cross-autocorrelation across the return distribution. The momentum factor is negatively cross-autocorrelated with the banking industry in the upper part of the distribution. These results can be compared with the OLS estimates presented in the second column of Table 9 .

[Insert Table 12]

Tables 13 to 15 present the quantile regression results for the financial crisis period before the Dodd-Frank Act, January 2004 to July 2010. For many industries the autocorrelation in Table 13 is high and positive in the extreme lower part of the distribution, $\tau=0.10$. For defense (guns) and textiles (txtls) it is negative. In the extreme upper part the autocorrelation appears as negative. There are, however very few statistical significances. The cross-autocorrelations in Table 14 are more dramatic. All statistically significant coefficients are positive and especially in the lower tail the coefficients are high. For entertainment (fun), and textiles (txtls) the coefficients are close to one. For the risk factors in Table 15 only momentum and investment factors are autocorrelated. Momentum has a positive autocorrelation in the lower tail whereas the investment factor is autocorrelated in the upper tail of the distribution. There is crossautocorrelation with banking industry in the lower tail for the market factor and in the upper tail for size.

[Insert Table 13]

[Insert Table 14]

[Insert Table 15]

Tables 16 to 18 presents the corresponding quantile regression results for the post DoddFrank Act period, August 2010 to February 2017. For this period there is a mixture of occasional 
significant positive and negative autocorrelation in Table 16 but these autocorrelation appears not to be robust over the different parts of the return distribution. In contrast to the pre DoddFrank Act period, the conditional cross-autocorrelation coefficients with the banking industry shown in Table 17 are now occurring mainly in the upper part of the distribution and are negative. A few significant positive cross-autocorrelations still are seen in the extreme negative tail of the return distribution.

For the risk factors in Table 18 there are hardly any autocorrelation structure left after the Dodd-Frank Act. The size factor is negatively autocorrelated in the extreme upper tail. The value factor is positively autocorrelated in the center of the distribution, and the profitability factor is significantly positively autocorrelated for the extreme of $\tau=0.90$. The crossautocorrelations are also mostly lost for this period. The value factor is positively crossautocorrelated with banks $\tau=0.80$ and 0.90 and the profitability factor is negatively crossautocorrelated with banks for $\tau=0.10$.

[Insert Table 16]

[Insert Table 17]

[Insert Table 18]

Figure 1 shows the asymmetry of the average conditional first order autocorrelation from the quantile regressions for the 47 industry portfolios over the return distribution. On average the autocorrelation is positive in the negative part and negative for the positive part of the conditional return distribution. However, the autocorrelation is on average lower and negative for the financial crisis sub period before the Dodd-Frank Act, January 2004 to July 2010.

\section{[Insert Figure 1]}

For the average conditional first order cross-autocorrelations shown in Figure 2 the situation is different. For the total sample January 1970 to February 2017 and for the financial crisis sub period before the Dodd-Frank Act, January 2004 to July 2010 the coefficient is positive and especially high for financial crises sub period. The average conditional crossautocorrelation is dramatically lower after the implementation of the Dodd-Frank Act and 
becomes negative for values of $\tau>0.20$. For this latter period the asymmetry of the crossautocorrelation has also increased.

[Insert Figure 2]

Figure 3 shows the average of the adjusted R-squares over the 47 industry quantile regressions. This average can be interpreted as the average predictability performance for the conditional regression model (3). Overall, the predictability is on average low. However, the average R-square is very asymmetric across the conditional return distribution especially for the two sub-samples. For the financial crisis period before the Dodd-Frank Act, January 2004 to July 2010, the predictability is much higher in the lower part of the return distribution whereas for the sub sample after the Dodd-Frank Act, August 2010 to February 2017, the predictability asymmetry is reversed and is now higher in the upper part of the conditional return distribution. Even for the total sample period the predictability is almost twice as high in the extreme negative part $(\tau=0.1)$ than it is in other parts of the distribution.

[Insert Figure 3]

\section{Summary and Conclusion}

The purpose of this empirical study is to revisit the issue of dynamic linkages between equity returns on different industry portfolios and contribute to the discussion by specifically focusing on the role of the banking industry portfolio and the effect of the implementation of the DoddFrank Wall Street Reform and Consumer Protection Act in 2010. Using monthly returns on 48 US industry portfolios, the results show that the dynamic linkages between the returns on the banking industry portfolio and other industries often are asymmetric in two ways. First, there appears to be a one-directional causality relation running from the banking industry to several other industries but seldom the other way around. Lagged returns on the banking industry portfolio seem to be able to predict returns on several other industry portfolios. For many industry portfolio returns the banking industry portfolio can be regarded as exogenous and Granger cause several other industry portfolio returns. Second, the cross-autocorrelation is found to be asymmetric such that on average the impact of a one-month lag of the return of the banking 
portfolio is more than twice as high in the lower part of the conditional return distribution than in the upper part. It is also found that returns on the banking industry portfolio seem to be dynamically connected to four of the six classic asset-pricing risk factors. These are the market, size, value, momentum, and investment risk factors. However, this dynamic relationship is not robust across the return distribution and can hence be regarded as endogenous.

After the implementation of the Dodd-Frank Act in August 2010 the dynamic linkages between returns on the banking industry and other industry portfolios changed. In the subsample before the implementation the Granger causality from the banking industry was especially high. However, for the subsample after the implementation of the Dodd-Frank Act this Granger causality almost disappears. A corresponding effect is observed for the conditional crossautocorrelation with the banking industry. In the subsample before the implementation this crossautocorrelation is very high and positive whereas it is lower and becomes negative in the post implementation subsample.

Overall, as expected the predictability of the conditional regression models are low. However, the predictability is not robust across the return distribution and is on average about twice as high in the extreme tails than in the center of the return distribution. For the subsample before the Dodd-Frank Act the predictability was much higher in the negative part of the conditional return distribution than in the positive part. For the post Dodd-Frank Act subsample this is reversed. The predictability is now more pronounced in the extreme positive part and almost nonexistent in the center of the distribution. 


\section{References}

Altay, E. (2004). Cross-autocorrelation between small and large cap portfolios in the German and Turkish stock markets. Journal of Financial Management and Analysis 17, 77-92.

Anari, A., Kolari, J. \& Mason, J. (2004). Further evidence of nonmonetary effects on the U.S. economy during the Great Depression. Journal of Money, Credit and Banking 28, 23312351.

Anderson, R., Eom, K., Hahn, S. \& Park, J.-H. (2013). Autocorrelation and partial price adjustment. Journal of Empirical Finance 24, 78-93.

Ayers, B. \& Freeman, R. (2000). Why do large firms' prices anticipate earnings earlier than small firms' prices? Contemporary Accounting Research 17, 191-212.

Baur, D., Dimpfl, T. \& Jung, R. (2012). Stock return autocorrelation revisited: A quantile regression approach. Journal of Empirical Finance 19, 254-265.

Bernanke, B. (1993). Credit in the macro economy. Federal Reserve Bank of New York Quarterly Review. 257-276.

Bernanke, B. \& Gertler, M. (1995). Inside the black box: The credit channel of monetary policy transmission. NBER Working Papers 5146, National Bureau of Economic Research, Inc.

Bernhardt, D. \& Mahani, R. (2007). Asymmetric information and stock return crossautocorrelations. Economic Letters 96, 14-22.

Carhart, M. M. (1997). On persistence in mutual fund performance. The Journal of Finance LII 57-82.

Cen, L., Chen, K., Dasgupta, S. \& Gao, N. (2013). When the tail wags the dog: Industry leaders, limited attention and spurious cross-industry information diffusion. Management Science $59,2566-2585$.

Chan, K. (1993). Imperfect information and cross-autocorrelation among stock prices. Journal of Finance XLVIII, 1211-1230.

Chen, S-S. (2007). Does Monetary Policy Have Asymmetric Effects on Stock Returns?, Journal of Money, Credit and Banking 39, 667-688

Chou, P.-H., Ho, P.-H. \& Ko, K.-C. (2013). Do industries matter in explaining stock returns and asset-pricing anomalies? Journal of Banking \& Finance 36, 355-370.

Doong, S.-H., Yang, S.-Y. \& Chiang, T. (2005). Response asymmetries in Asian stock markets. Review of Pacific Basin Financial Markets and Policies 8, 637-657. 
Fama, E. F. and French, K. R. (1993). Common risk factors in the returns on stocks and bonds. Journal of Financial Economics 33, 3-56.

Fama, E. F. and French, K. R. (2015). A five-factor asset pricing model. Journal of Financial Economics 116, 1-22.

Gorton, G., and Winton, A. (2002), Financial Intermediaries, Chapter in the Handbook of Economics and Finance, Volume 1, 431-552.

Hameed, A. (1997). Time-varying factors and cross-autocorrelations in short-horizon stock returns. Journal of Financial Research 20, 435-458.

Hammami Y. \& Lindahl, A. (2014). An intertemporal capital asset pricing model with bank credit growth as a state variable. Journal of Banking and Finance 39, 14-28.

Hong, H., Torous, W. \& Valkanov, R. (2007). Do industries lead stock markets? Journal of Financial Economics 83, 367-396.

Hou, K. (2007). Industry information diffusion and the lead-lag effect in stock returns. Review of Financial Studies 20, 1113-1138.

Högholm, K., J. Knif, and G. Koutmos, (2014), Asymmetric dynamic linkages between returns on banks and other industry portfolio returns, in Contributions to Mathematics, Statistics, Econometrics, and Finance, Essays in the Honour of Professor Seppo Pynnönen, Acta Wasaensia 296, 209-230.

Högholm, K., Knif, J., Koutmos, G. \& Pynnönen, S. (2011). Distributional asymmetry of loadings on market co-moments. Journal of International Financial Markets, Institutions \& Money 21, 851-866.

Högholm, K., Knif, J. \& Pynnönen, S. (2011a). Cross-distributional robustness of weekday effects: Evidence from European equity index returns. European Journal of Finance 17, $377-390$.

Högholm, K., Knif, J. \& Pynnönen, S. (2011b). Fund performance robustness: An evaluation using European large-cap equity funds. Frontiers in Finance and Economics 8, 1-26.

Kinnunen, J. (2013). Dynamic cross-autocorrelation in stock returns. In Risk-return trade-off and autocorrelation. $\mathrm{PhD}$ dissertation. Acta Universitatis Lappeenrantaensis 511. Lappeenranta University of Technology.

Koenker, R. (2005). Quantile Regression. New York: Cambridge University Press. Koenker, R. \& Bassett, G. (1978). Regression quantiles. Econometrica 4, 41-55. 
Laopodis, N. (2016). Industry returns, market returns and economic fundamentals: Evidence for the United States, Economic Modelling 53, 89-106.

Lee, C.-C., Chen, M.-P. \& Chang, C.-H. (2013). Dynamic relationships between industry returns and stock market returns. North American Journal of Economics and Finance 26, 119-144.

Lo, A. \& MacKinley, C. (1990a). An econometric analysis of nonsynchronous trading. Journal of Econometrics 45, 181-211.

Lo, A. \& MacKinley, C. (1990b). When are contrarian profits due to stock market overreaction? Review of Financial Studies 3, 175-205.

McQueen, G., Pinegar, M. \& Thorley, S. (1996). Delayed reaction to good news and the crossautocorrelation of portfolio returns. Journal of Finance LI, 889-919.

Merton, R. (1987). A simple model of capital market equilibrium with incomplete information. Journal of Finance XLII, 483-510.

Tse, Y. (2015). Do industries lead stock markets? A reexamination. Journal of Empirical Finance 34, 195-203.

Zebedee A. \& Kasch-Haroutounian, M. (2009). A closer look at co-movements among stock returns. Journal of Economics and Business 61, 279-294. 
Table 1. Banking industry portfolio structure - Kenneth French gives the following description: We assign each NYSE, AMEX, and NASDAQ stock to an industry portfolio at the end of June of year $t$ based on its four-digit SIC code at that time. However, we use not only CRSP, but also Compustat as a source of SIC codes. We use Compustat SIC codes (for the fiscal year ending in calendar year t-1) whenever available. Otherwise, we use CRSP SIC codes (for June of year t).

\begin{tabular}{ll}
\hline Banking & \\
\hline 6000-6000 Depository institutions & 6010-6019 Federal reserve banks \\
6020-6020 Commercial banks & $6021-6021$ National commercial banks \\
6022-6022 State banks - Fed Res System & 6023-6024 State banks - not Fed Res System \\
6025-6025 National banks - Fed Res System & 6026-6026 National banks - not Fed Res System \\
6027-6027 National banks, not FDIC & 6028-6029 Banks \\
6030-6036 Savings institution & 6040-6059 Banks (Other) \\
6060-6062 Credit unions & 6080-6082 Foreign banks \\
6090-6099 Functions related to deposit banking & 6100-6100 Non-depository credit institutions \\
6110-6111 Federal credit agencies & 6112-6113 FNMA \\
6120-6129 S\&Ls & 6130-6139 Agricultural credit institutions \\
6140-6149 Personal credit institutions & 6150-6159 Business credit institutions \\
6160-6169 Mortgage bankers & 6170-6179 Finance lessors \\
6190-6199 Financial services &
\end{tabular}


Table 2. Descriptive statistics for the return distribution of 566 monthly returns on 48 US industry portfolios over the total sample period from January 1970 to February 2017

\begin{tabular}{|c|c|c|c|c|c|c|c|c|}
\hline & Mean & Maximum & Minimum & Std. Dev. & Skewness & Kurtosis & $\begin{array}{c}\text { Jarque- } \\
\text { Bera }\end{array}$ & Prob. \\
\hline aero & 1.23 & 25.33 & -30.23 & 6.68 & -0.38 & 5.00 & 107.19 & 0.00 \\
\hline agric & 0.99 & 28.88 & -28.79 & 6.47 & 0.00 & 4.79 & 75.48 & 0.00 \\
\hline autos & 0.87 & 49.57 & -36.41 & 7.03 & 0.21 & 8.74 & 781.87 & 0.00 \\
\hline banks & 1.00 & 25.03 & -27.25 & 6.12 & -0.30 & 5.07 & 109.86 & 0.00 \\
\hline beer & 1.14 & 26.09 & -19.76 & 5.28 & -0.05 & 5.46 & 143.29 & 0.00 \\
\hline bldmt & 1.03 & 35.51 & -30.67 & 6.29 & -0.04 & 7.01 & 380.09 & 0.00 \\
\hline books & 0.90 & 30.74 & -25.19 & 5.92 & 0.03 & 5.13 & 107.37 & 0.00 \\
\hline boxes & 1.01 & 20.87 & -28.24 & 5.80 & -0.42 & 4.92 & 103.74 & 0.00 \\
\hline bussv & 1.08 & 25.43 & -27.54 & 6.61 & -0.17 & 4.33 & 44.34 & 0.00 \\
\hline chems & 1.06 & 22.05 & -28.00 & 5.73 & -0.15 & 5.24 & 119.87 & 0.00 \\
\hline chips & 1.05 & 27.27 & -32.23 & 7.62 & -0.38 & 4.63 & 76.41 & 0.00 \\
\hline clths & 1.08 & 32.37 & -30.90 & 6.66 & -0.04 & 5.51 & 149.24 & 0.00 \\
\hline cnstr & 0.88 & 24.01 & -31.10 & 7.27 & -0.12 & 3.94 & 22.14 & 0.00 \\
\hline coal & 1.02 & 46.06 & -37.94 & 10.97 & 0.18 & 4.63 & 65.81 & 0.00 \\
\hline comps & 0.87 & 24.24 & -32.36 & 7.19 & -0.17 & 4.60 & 63.05 & 0.00 \\
\hline drugs & 1.07 & 31.80 & -19.11 & 5.09 & 0.15 & 5.73 & 177.66 & 0.00 \\
\hline elceq & 1.16 & 23.22 & -32.20 & 6.35 & -0.22 & 4.71 & 73.41 & 0.00 \\
\hline fabpr & 0.72 & 30.38 & -26.67 & 7.35 & -0.13 & 4.28 & 40.49 & 0.00 \\
\hline fin & 1.12 & 19.56 & -25.91 & 6.30 & -0.46 & 4.29 & 58.99 & 0.00 \\
\hline food & 1.14 & 19.59 & -17.88 & 4.51 & 0.12 & 5.13 & 108.41 & 0.00 \\
\hline fun & 1.30 & 38.77 & -31.86 & 7.80 & -0.23 & 6.04 & 222.61 & 0.00 \\
\hline gold & 0.96 & 78.68 & -33.57 & 10.97 & 0.77 & 7.52 & 537.24 & 0.00 \\
\hline guns & 1.33 & 32.64 & -30.08 & 6.56 & -0.20 & 5.41 & 140.87 & 0.00 \\
\hline hlth & 0.98 & 36.47 & -39.11 & 8.17 & -0.06 & 5.69 & 170.93 & 0.00 \\
\hline hshld & 0.86 & 18.54 & -21.64 & 4.73 & -0.29 & 4.99 & 101.60 & 0.00 \\
\hline insur & 1.07 & 26.84 & -26.46 & 5.57 & -0.29 & 5.19 & 121.36 & 0.00 \\
\hline labeq & 1.00 & 22.04 & -30.15 & 7.25 & -0.18 & 4.20 & 37.09 & 0.00 \\
\hline mach & 1.00 & 23.05 & -31.19 & 6.40 & -0.41 & 5.37 & 147.72 & 0.00 \\
\hline meals & 1.05 & 27.88 & -31.28 & 6.10 & -0.56 & 5.89 & 226.18 & 0.00 \\
\hline medeq & 0.99 & 21.03 & -20.56 & 5.31 & -0.37 & 4.39 & 58.85 & 0.00 \\
\hline mines & 1.04 & 26.91 & -34.75 & 7.68 & -0.32 & 4.83 & 88.28 & 0.00 \\
\hline oil & 1.06 & 24.66 & -18.21 & 5.60 & 0.07 & 4.13 & 30.45 & 0.00 \\
\hline other & 0.55 & 21.19 & -26.37 & 6.86 & -0.46 & 4.54 & 75.28 & 0.00 \\
\hline paper & 1.01 & 24.27 & -26.35 & 5.59 & 0.10 & 5.36 & 132.24 & 0.00 \\
\hline persv & 0.61 & 24.47 & -28.25 & 6.77 & -0.29 & 4.60 & 67.78 & 0.00 \\
\hline rlest & 0.54 & 59.60 & -37.73 & 7.63 & 0.60 & 12.61 & 2213.44 & 0.00 \\
\hline rtail & 1.06 & 27.07 & -29.17 & 5.55 & -0.19 & 5.16 & 113.29 & 0.00 \\
\hline rubbr & 1.05 & 31.95 & -30.57 & 6.04 & -0.25 & 5.98 & 215.67 & 0.00 \\
\hline ships & 1.12 & 29.15 & -32.27 & 7.43 & -0.01 & 4.50 & 52.82 & 0.00 \\
\hline smoke & 1.49 & 32.47 & -24.93 & 6.22 & -0.11 & 5.64 & 165.86 & 0.00 \\
\hline soda & 1.11 & 38.27 & -26.26 & 6.59 & 0.15 & 6.98 & 375.25 & 0.00 \\
\hline steel & 0.78 & 30.67 & -32.91 & 7.66 & -0.21 & 5.06 & 104.45 & 0.00 \\
\hline telcm & 0.98 & 21.34 & -16.22 & 4.76 & -0.25 & 4.21 & 40.29 & 0.00 \\
\hline toys & 0.81 & 26.88 & -34.41 & 7.09 & -0.24 & 4.51 & 59.27 & 0.00 \\
\hline $\operatorname{trans}$ & 1.01 & 19.02 & -27.90 & 5.83 & -0.24 & 4.32 & 46.42 & 0.00 \\
\hline txtls & 1.04 & 59.04 & -32.51 & 7.36 & 0.51 & 12.48 & 2143.42 & 0.00 \\
\hline util & 0.93 & 18.84 & -12.65 & 4.10 & -0.14 & 4.06 & 28.60 & 0.00 \\
\hline whlsl & 0.97 & 18.12 & -28.64 & 5.50 & -0.35 & 5.65 & 176.91 & 0.00 \\
\hline
\end{tabular}


Table 3. Descriptive statistics for the return distribution of 566 monthly returns on six risk factors over the total sample period from January 1970 to February 2017

\begin{tabular}{lccccccccc}
\hline & & & & & & & & \multicolumn{3}{c}{ Jarque- } \\
& Mean & \multicolumn{1}{c}{ Maximum } & \multicolumn{1}{c}{ Minimum } & Std. Dev. & Skewness & Kurtosis & Bera & Prob. \\
\hline Market & 0.54 & 16.10 & -23.24 & 4.55 & -0.54 & 4.89 & 112.37 & 0.00 \\
Size & 0.19 & 18.73 & -15.28 & 3.06 & 0.42 & 6.87 & 369.26 & 0.00 \\
Value & 0.39 & 12.91 & -11.25 & 2.92 & 0.05 & 5.01 & 95.68 & 0.00 \\
Momentum & 0.63 & 18.38 & -34.58 & 4.39 & -1.34 & 13.20 & 2624.40 & 0.00 \\
Investment & 0.35 & 9.55 & -6.88 & 2.00 & 0.33 & 4.67 & 76.46 & 0.00 \\
Profitability & 0.27 & 13.52 & -19.11 & 2.31 & -0.39 & 16.06 & 4035.88 & 0.00 \\
\hline
\end{tabular}


Table 4. Partial autocorrelation coefficients for 566 monthly returns on 48 US industry portfolios for the total sample January 1970 to February 2017, and for two subsamples (79 returns), before and after the Dodd-Frank Act. Bold values are significant for levels of $10 \%$ or lower.

\begin{tabular}{|c|c|c|c|c|c|c|}
\hline & Total sample & & $\begin{array}{r}\text { January2004- } \\
\text { July2010 } \\
\end{array}$ & & $\begin{array}{l}\text { ugust2010- } \\
\text { bruary2017 }\end{array}$ & \\
\hline & lag 1 & $\operatorname{lag} 2$ & lag 1 & $\operatorname{lag} 2$ & $\operatorname{lag} 1$ & $\operatorname{lag} 2$ \\
\hline aero & 0.141 & -0.057 & 0.084 & -0.038 & -0.050 & 0.081 \\
\hline agric & 0.015 & -0.026 & -0.064 & 0.036 & -0.236 & -0.124 \\
\hline autos & 0.117 & -0.064 & 0.054 & -0.158 & -0.052 & 0.042 \\
\hline banks & 0.114 & -0.053 & 0.314 & -0.206 & -0.037 & -0.028 \\
\hline beer & 0.025 & -0.032 & 0.073 & -0.177 & -0.169 & -0.098 \\
\hline bldmt & 0.086 & -0.086 & 0.026 & 0.016 & -0.174 & 0.052 \\
\hline books & 0.179 & -0.038 & -0.052 & -0.145 & -0.220 & -0.049 \\
\hline boxes & 0.029 & -0.039 & 0.098 & -0.060 & -0.086 & -0.018 \\
\hline bussv & 0.072 & -0.039 & -0.038 & -0.067 & -0.240 & -0.098 \\
\hline chems & 0.024 & -0.052 & -0.040 & -0.099 & -0.116 & -0.072 \\
\hline chips & 0.054 & 0.008 & -0.018 & 0.000 & -0.070 & 0.064 \\
\hline clths & 0.169 & -0.049 & 0.115 & -0.221 & -0.157 & -0.040 \\
\hline cnstr & 0.121 & -0.040 & 0.111 & -0.066 & -0.107 & 0.030 \\
\hline coal & 0.045 & 0.119 & 0.022 & 0.126 & -0.004 & 0.190 \\
\hline drugs & -0.031 & 0.017 & -0.101 & 0.060 & -0.114 & 0.010 \\
\hline comps & 0.054 & 0.004 & 0.009 & 0.015 & -0.165 & -0.038 \\
\hline elceq & 0.022 & -0.045 & -0.037 & -0.080 & -0.041 & 0.125 \\
\hline fabpr & 0.100 & -0.011 & 0.070 & -0.039 & -0.009 & 0.064 \\
\hline fin & 0.162 & -0.081 & 0.057 & -0.195 & -0.029 & 0.022 \\
\hline food & 0.049 & -0.007 & 0.058 & 0.055 & -0.224 & 0.039 \\
\hline fun & 0.169 & -0.053 & 0.113 & -0.091 & -0.068 & -0.017 \\
\hline gold & -0.035 & -0.054 & -0.205 & -0.161 & -0.005 & 0.092 \\
\hline guns & 0.049 & -0.114 & 0.166 & -0.199 & 0.007 & 0.046 \\
\hline hlth & 0.167 & 0.013 & 0.128 & -0.059 & 0.079 & 0.059 \\
\hline hshld & 0.078 & -0.018 & -0.003 & 0.020 & -0.068 & -0.127 \\
\hline insur & 0.119 & -0.103 & -0.087 & 0.050 & -0.147 & 0.004 \\
\hline labeq & 0.097 & -0.039 & 0.093 & -0.042 & 0.029 & 0.075 \\
\hline mach & 0.081 & -0.033 & 0.102 & -0.079 & -0.118 & 0.089 \\
\hline meals & 0.145 & -0.016 & 0.161 & -0.058 & -0.098 & -0.095 \\
\hline medeq & 0.071 & -0.005 & 0.055 & -0.024 & -0.118 & 0.000 \\
\hline mines & 0.033 & 0.034 & 0.128 & 0.058 & -0.142 & 0.129 \\
\hline oil & -0.016 & -0.030 & -0.074 & -0.081 & 0.052 & 0.082 \\
\hline other & 0.120 & -0.041 & -0.011 & -0.071 & -0.174 & -0.002 \\
\hline paper & 0.017 & -0.071 & -0.081 & -0.008 & -0.062 & 0.025 \\
\hline persv & 0.103 & -0.036 & 0.256 & -0.210 & -0.228 & 0.172 \\
\hline rlest & 0.211 & -0.083 & 0.445 & -0.076 & 0.002 & -0.005 \\
\hline rtail & 0.145 & -0.069 & 0.110 & -0.168 & -0.219 & 0.018 \\
\hline rubbr & 0.097 & -0.022 & -0.007 & 0.055 & -0.153 & 0.107 \\
\hline ships & 0.062 & -0.070 & 0.063 & 0.037 & -0.065 & 0.017 \\
\hline smoke & 0.031 & -0.001 & 0.084 & 0.025 & -0.276 & -0.105 \\
\hline soda & 0.039 & -0.074 & -0.041 & -0.233 & -0.181 & 0.046 \\
\hline steel & 0.036 & -0.024 & -0.014 & -0.018 & -0.034 & 0.071 \\
\hline telcm & 0.046 & -0.034 & 0.064 & -0.010 & -0.099 & 0.032 \\
\hline toys & 0.078 & -0.060 & -0.021 & -0.195 & -0.198 & -0.143 \\
\hline trans & 0.090 & -0.071 & 0.082 & -0.170 & -0.020 & 0.032 \\
\hline txtls & 0.174 & -0.160 & 0.302 & -0.172 & -0.065 & 0.107 \\
\hline util & 0.049 & -0.076 & 0.037 & -0.079 & -0.223 & 0.007 \\
\hline whlsl & 0.140 & -0.028 & 0.115 & 0.000 & -0.102 & -0.005 \\
\hline
\end{tabular}


Table 5. Partial autocorrelation coefficients for 566 monthly returns on six risk factors for the total sample from January 1970 to February 2017, and for two subsamples (79 returns), before and after the Dodd-Frank Act. Significant values are indicated with bold for levels of $10 \%$ or lower.

\begin{tabular}{ccccccc}
\hline & & & January2004- & \multicolumn{3}{c}{$\begin{array}{c}\text { August2010- } \\
\text { February2017 }\end{array}$} \\
\hline & lag 1 & lag 2 & lag 1 & lag 2 & lag 1 & lag 2 \\
\hline Market & $\mathbf{0 . 0 8 4}$ & -0.046 & $\mathbf{0 . 3 8 0}$ & $\mathbf{- 0 . 2 3 8}$ & -0.147 & 0.003 \\
Size & 0.030 & 0.041 & -0.066 & -0.010 & $\mathbf{- 0 . 2 7 3}$ & -0.019 \\
Value & $\mathbf{0 . 1 6 6}$ & 0.011 & $\mathbf{0 . 3 2 8}$ & $\mathbf{- 0 . 2 0 9}$ & $\mathbf{0 . 2 2 0}$ & -0.042 \\
Momentum & $\mathbf{0 . 0 7 0}$ & -0.058 & $\mathbf{0 . 3 0 8}$ & -0.177 & -0.029 & 0.040 \\
Investment & $\mathbf{0 . 1 3 3}$ & 0.026 & 0.146 & 0.112 & 0.147 & 0.045 \\
Profitability & $\mathbf{0 . 1 4 6}$ & 0.010 & 0.147 & 0.026 & 0.164 & -0.089 \\
\hline
\end{tabular}


Table 6. Bivariate Granger causality tests with two lags for 566 monthly returns on 48 US industry portfolios for the total sample from January 1970 to February 2017, and for two subsamples (79 returns), before and after the Dodd-Frank Act. Significant values are indicated with bold for levels of $10 \%$ or lower.

\begin{tabular}{|c|c|c|c|c|c|c|}
\hline & \multicolumn{2}{|c|}{ Total sample } & \multicolumn{2}{|c|}{$\begin{array}{r}\text { January2004- } \\
\text { July2010 }\end{array}$} & \multicolumn{2}{|c|}{$\begin{array}{r}\text { August2010- } \\
\text { February2017 }\end{array}$} \\
\hline $\begin{array}{l}\text { Null } \\
\text { hypothesis: }\end{array}$ & $\begin{array}{l}\text { Banks } \\
\text { Granger } \\
\text { cause } \\
\text { Other } \\
\text { industry }\end{array}$ & $\begin{array}{l}\text { Other } \\
\text { industry } \\
\text { Granger } \\
\text { cause } \\
\text { Banking } \\
\text { industry }\end{array}$ & $\begin{array}{l}\text { Banks } \\
\text { Granger } \\
\text { cause } \\
\text { Other } \\
\text { industry }\end{array}$ & $\begin{array}{l}\text { Other } \\
\text { industry } \\
\text { Granger } \\
\text { cause } \\
\text { Banking } \\
\text { industry }\end{array}$ & $\begin{array}{l}\text { Banks } \\
\text { Granger } \\
\text { cause } \\
\text { Other } \\
\text { industry }\end{array}$ & $\begin{array}{l}\text { Other } \\
\text { industry } \\
\text { Granger } \\
\text { cause } \\
\text { Banking } \\
\text { industry }\end{array}$ \\
\hline $\begin{array}{l}\text { Other } \\
\text { industry }\end{array}$ & $\begin{array}{r}\text { F- } \\
\text { Statistic }\end{array}$ & $\begin{array}{r}\text { F- } \\
\text { Statistic } \\
\end{array}$ & $\begin{array}{r}\text { F- } \\
\text { Statistic }\end{array}$ & $\begin{array}{r}\text { F- } \\
\text { Statistic } \\
\end{array}$ & $\begin{array}{r}\text { F- } \\
\text { Statistic }\end{array}$ & $\begin{array}{r}\text { F- } \\
\text { Statistic } \\
\end{array}$ \\
\hline aero & 2.298 & 0.036 & 1.790 & 0.108 & 2.066 & 2.412 \\
\hline agric & 4.302 & 0.475 & 4.338 & 0.384 & 2.021 & 1.918 \\
\hline autos & 3.409 & 0.223 & 5.506 & 2.131 & 3.043 & 2.208 \\
\hline beer & 1.615 & 1.089 & 0.606 & 0.342 & 1.060 & 0.318 \\
\hline bldmt & 6.244 & 0.337 & 4.030 & 1.721 & 3.509 & 3.143 \\
\hline books & 1.630 & 2.202 & 3.912 & 3.536 & 1.135 & 0.748 \\
\hline boxes & 2.321 & 0.371 & 2.522 & 0.164 & 1.501 & 1.266 \\
\hline bussv & 1.161 & 0.837 & 3.499 & 1.573 & 0.329 & 0.369 \\
\hline chems & 1.686 & 0.036 & 9.451 & 3.525 & 2.014 & 0.989 \\
\hline chips & 4.815 & 0.247 & 5.809 & 1.149 & 2.212 & 3.182 \\
\hline clths & 0.049 & 1.506 & 4.684 & 0.584 & 1.242 & 0.143 \\
\hline cnstr & 3.697 & 0.601 & 3.316 & 0.519 & 1.651 & 2.383 \\
\hline coal & 1.624 & 3.672 & 5.122 & 1.338 & 1.592 & 0.894 \\
\hline drugs & 4.122 & 0.259 & 7.108 & 3.156 & 1.502 & 0.050 \\
\hline comps & 0.973 & 1.243 & 0.725 & 0.757 & 0.193 & 0.350 \\
\hline elceq & 3.834 & 0.055 & 4.074 & 0.280 & 5.341 & 3.435 \\
\hline fabpr & 9.909 & 0.239 & 9.715 & 1.816 & 2.412 & 0.120 \\
\hline fin & 1.161 & 1.397 & 3.118 & 1.854 & 4.396 & 4.294 \\
\hline food & 0.683 & 0.648 & 4.930 & 0.662 & 0.022 & 0.515 \\
\hline fun & 3.591 & 0.604 & 8.271 & 0.893 & 0.145 & 0.911 \\
\hline gold & 0.936 & 1.118 & 0.988 & 0.400 & 2.914 & 0.181 \\
\hline guns & 4.084 & 0.996 & 10.153 & 0.659 & 0.175 & 0.505 \\
\hline hlth & 5.210 & 0.118 & 6.261 & 0.177 & 0.754 & 0.905 \\
\hline hshld & 3.196 & 0.129 & 2.574 & 0.821 & 0.273 & 0.800 \\
\hline insur & 0.464 & 1.252 & 0.413 & 0.490 & 0.974 & 0.909 \\
\hline labeq & 3.224 & 0.385 & 4.154 & 2.354 & 0.719 & 1.187 \\
\hline mach & 4.419 & 0.213 & 4.038 & 2.056 & 5.738 & 3.266 \\
\hline meals & 1.843 & 0.227 & 3.602 & 0.783 & 1.803 & 0.089 \\
\hline medeq & 2.326 & 1.709 & 5.275 & 1.934 & 0.404 & 0.286 \\
\hline mines & 3.309 & 0.855 & 2.172 & 1.655 & 6.195 & 4.359 \\
\hline oil & 0.737 & 2.058 & 4.710 & 2.061 & 5.055 & 1.482 \\
\hline other & 0.716 & 1.392 & 2.613 & 2.016 & 0.888 & 1.051 \\
\hline paper & 5.393 & 0.197 & 3.663 & 2.788 & 1.372 & 1.032 \\
\hline persv & 0.804 & 0.137 & 2.492 & 1.542 & 0.480 & 0.943 \\
\hline rlest & 8.167 & 0.740 & 8.830 & 0.591 & 0.634 & 0.097 \\
\hline rtail & 0.065 & 1.139 & 0.713 & 0.910 & 1.248 & 0.136 \\
\hline
\end{tabular}


Table 6. (Continued) Bivariate Granger causality tests with two lags for 566 monthly returns on 48 US industry portfolios for the total sample from January 1970 to February 2017, and for two subsamples (79 returns), before and after the Dodd-Frank Act. Significant values are indicated with bold for levels of $10 \%$ or lower.

\begin{tabular}{|c|c|c|c|c|c|c|}
\hline & \multicolumn{2}{|c|}{ Total sample } & \multicolumn{2}{|c|}{$\begin{array}{r}\text { January2004- } \\
\text { July2010 }\end{array}$} & \multicolumn{2}{|c|}{$\begin{array}{r}\text { August2010- } \\
\text { February2017 }\end{array}$} \\
\hline $\begin{array}{l}\text { Null } \\
\text { hypothesis: }\end{array}$ & $\begin{array}{l}\text { Banks } \\
\text { Granger } \\
\text { cause } \\
\text { Other } \\
\text { industry }\end{array}$ & $\begin{array}{l}\text { Other } \\
\text { industry } \\
\text { Granger } \\
\text { cause } \\
\text { Banking } \\
\text { industry }\end{array}$ & $\begin{array}{l}\text { Banks } \\
\text { Granger } \\
\text { cause } \\
\text { Other } \\
\text { industry }\end{array}$ & $\begin{array}{l}\text { Other } \\
\text { industry } \\
\text { Granger } \\
\text { cause } \\
\text { Banking } \\
\text { industry }\end{array}$ & $\begin{array}{l}\text { Banks } \\
\text { Granger } \\
\text { cause } \\
\text { Other } \\
\text { industry }\end{array}$ & $\begin{array}{l}\text { Other } \\
\text { industry } \\
\text { Granger } \\
\text { cause } \\
\text { Banking } \\
\text { industry }\end{array}$ \\
\hline $\begin{array}{l}\text { Other } \\
\text { industry }\end{array}$ & $\begin{array}{r}\text { F- } \\
\text { Statistic }\end{array}$ & $\begin{array}{r}\text { F- } \\
\text { Statistic }\end{array}$ & $\begin{array}{r}\text { F- } \\
\text { Statistic }\end{array}$ & $\begin{array}{r}\text { F- } \\
\text { Statistic }\end{array}$ & $\begin{array}{r}\text { F- } \\
\text { Statistic } \\
\end{array}$ & $\begin{array}{r}\text { F- } \\
\text { Statistic }\end{array}$ \\
\hline rubbr & 11.651 & 0.060 & 6.625 & 1.667 & 3.197 & 2.643 \\
\hline ships & 3.121 & 0.657 & 5.889 & 0.436 & 1.917 & 2.064 \\
\hline smoke & 0.364 & 1.146 & 3.671 & 3.875 & 0.673 & 0.804 \\
\hline soda & 1.870 & 0.099 & 4.775 & 0.406 & 0.497 & 0.173 \\
\hline steel & 6.686 & 0.617 & 5.944 & 0.536 & 5.506 & 2.476 \\
\hline telcm & 2.279 & 0.086 & 3.655 & 1.176 & 0.687 & 0.892 \\
\hline toys & 4.440 & 0.602 & 0.695 & 0.039 & 1.639 & 1.449 \\
\hline trans & 1.533 & 0.100 & 2.888 & 0.552 & 4.393 & 3.341 \\
\hline txtls & 4.783 & 1.552 & 10.823 & 0.939 & 0.698 & 0.940 \\
\hline util & 0.155 & 0.519 & 3.560 & 1.209 & 0.274 & 1.916 \\
\hline whlsl & 2.303 & 0.740 & 5.759 & 0.892 & 1.491 & 1.581 \\
\hline
\end{tabular}


Table 7. Bivariate Granger causality tests with two lags for 566 monthly returns risk factors for the total sample from January 1970 to February 2017, and for two subsamples (79 returns), before and after the Dodd-Frank Act. Significant values are indicated with bold for levels of $10 \%$ or lower.

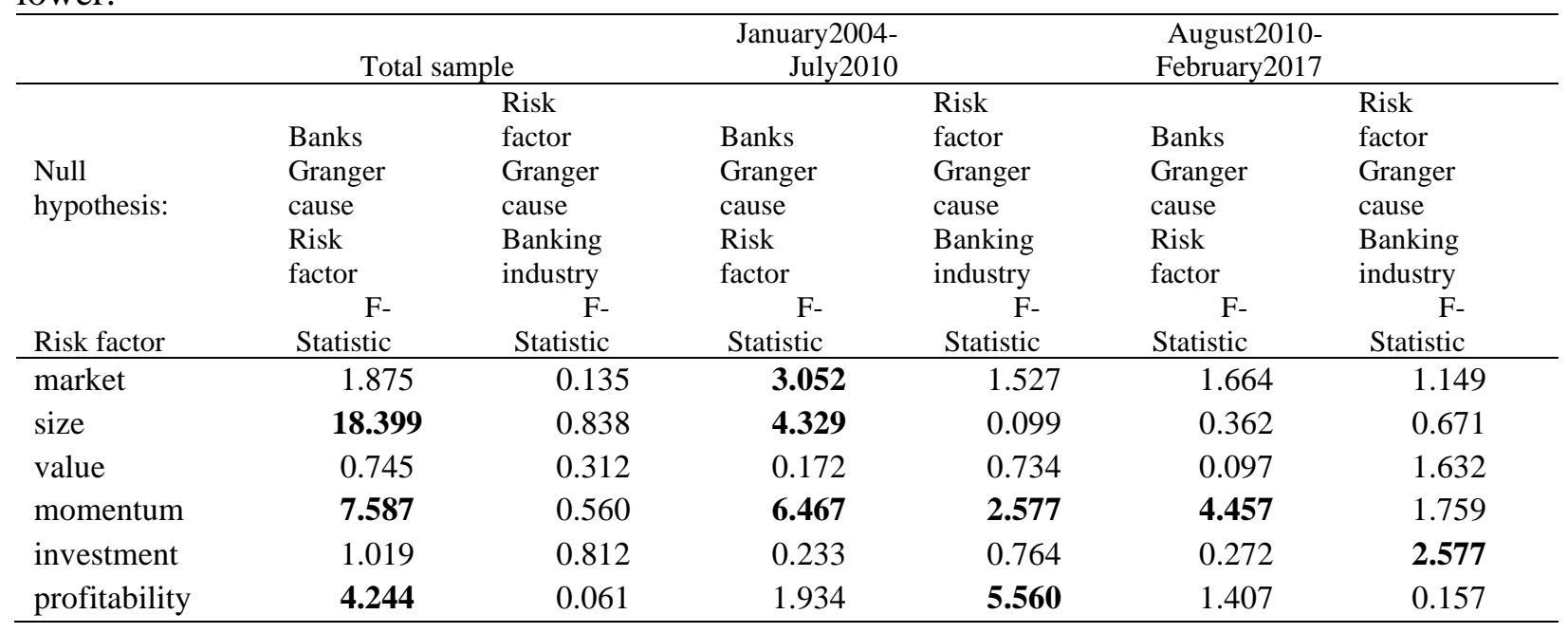


Table 8. Benchmark OLS regression estimates of $r_{t}^{\text {ind }}=\beta_{0}+\beta_{1} r_{t-1}^{\text {ind }}+\beta_{2} r_{t-1}^{\text {banks }}+\varepsilon_{t}^{\text {ind }}$ total sample (566 returns) from January 1970 to February 2017, and for two subsamples (79 returns), before and after the Dodd-Frank Act. Significant values are indicated with bold for levels of 10\% or lower.

\begin{tabular}{|c|c|c|c|c|c|c|}
\hline & Total sal & & $\begin{array}{r}\text { January2004- } \\
\text { July2010 } \\
\end{array}$ & & $\begin{array}{l}\text { August2010- } \\
\text { February2017 }\end{array}$ & \\
\hline & $\beta_{1}$ & $\beta_{2}$ & $\beta_{1}$ & $\beta_{2}$ & $\beta_{1}$ & $\beta_{2}$ \\
\hline aero & 0.066 & 0.111 & -0.153 & 0.410 & 0.094 & -0.177 \\
\hline agric & -0.033 & 0.101 & 0.236 & -0.089 & -0.295 & 0.211 \\
\hline autos & 0.024 & 0.148 & 0.019 & 0.333 & 0.202 & -0.438 \\
\hline beer & -0.023 & 0.071 & -0.177 & 0.077 & -0.113 & -0.092 \\
\hline bldmt & -0.079 & 0.215 & -0.070 & 0.357 & -0.177 & -0.012 \\
\hline books & 0.134 & 0.051 & 0.211 & 0.196 & -0.158 & -0.071 \\
\hline boxes & -0.003 & 0.043 & 0.033 & 0.097 & -0.093 & 0.011 \\
\hline bussv & 0.035 & 0.058 & 0.182 & 0.080 & -0.127 & -0.098 \\
\hline chems & -0.016 & 0.052 & 0.219 & 0.073 & 0.018 & -0.184 \\
\hline chips & 0.013 & 0.086 & 0.067 & 0.105 & 0.080 & -0.223 \\
\hline clths & 0.153 & 0.012 & -0.041 & 0.338 & -0.059 & -0.194 \\
\hline cnstr & 0.020 & 0.172 & 0.028 & 0.226 & -0.072 & -0.061 \\
\hline coal & 0.049 & 0.004 & 0.171 & 0.497 & 0.031 & -0.233 \\
\hline drugs & -0.058 & 0.035 & -0.036 & 0.037 & -0.074 & -0.057 \\
\hline comps & 0.020 & 0.078 & 0.082 & 0.208 & 0.025 & -0.265 \\
\hline elceq & -0.070 & 0.136 & -0.055 & 0.264 & -0.010 & -0.062 \\
\hline fabpr & 0.007 & 0.206 & 0.034 & 0.343 & 0.038 & -0.134 \\
\hline fin & 0.126 & 0.026 & 0.494 & -0.177 & 0.057 & -0.101 \\
\hline food & 0.013 & 0.041 & -0.134 & 0.194 & -0.239 & 0.011 \\
\hline fun & 0.105 & 0.107 & 0.026 & 0.491 & -0.026 & -0.094 \\
\hline gold & -0.029 & -0.082 & -0.152 & -0.213 & -0.043 & -0.552 \\
\hline guns & -0.015 & 0.125 & -0.195 & 0.341 & 0.042 & -0.051 \\
\hline hlth & 0.118 & 0.138 & 0.032 & 0.246 & 0.185 & -0.170 \\
\hline hshld & -0.010 & 0.101 & -0.054 & 0.178 & -0.017 & -0.051 \\
\hline insur & 0.088 & 0.016 & 0.145 & 0.109 & -0.199 & 0.047 \\
\hline labeq & 0.042 & 0.109 & 0.087 & 0.207 & 0.130 & -0.134 \\
\hline mach & 0.019 & 0.092 & 0.144 & 0.164 & -0.073 & -0.098 \\
\hline meals & 0.104 & 0.052 & -0.100 & 0.193 & 0.051 & -0.152 \\
\hline medeq & 0.014 & 0.074 & 0.078 & 0.173 & -0.080 & -0.051 \\
\hline mines & -0.007 & 0.104 & 0.063 & 0.170 & -0.091 & -0.231 \\
\hline oil & -0.044 & 0.052 & -0.103 & 0.291 & 0.140 & -0.147 \\
\hline other & 0.072 & 0.075 & -0.006 & 0.290 & -0.107 & -0.073 \\
\hline paper & -0.102 & 0.156 & -0.028 & 0.291 & 0.079 & -0.157 \\
\hline persv & 0.059 & 0.072 & -0.150 & 0.207 & -0.209 & -0.124 \\
\hline rlest & 0.056 & 0.267 & -0.077 & 0.707 & 0.125 & -0.196 \\
\hline rtail & 0.144 & -0.013 & 0.154 & 0.001 & -0.112 & -0.123 \\
\hline rubbr & -0.063 & 0.235 & -0.143 & 0.466 & -0.184 & 0.011 \\
\hline ships & -0.002 & 0.123 & -0.090 & 0.485 & 0.077 & -0.308 \\
\hline smoke & 0.017 & 0.036 & -0.154 & 0.203 & -0.225 & -0.102 \\
\hline soda & 0.021 & 0.029 & 0.082 & 0.120 & -0.186 & -0.013 \\
\hline steel & -0.042 & 0.172 & 0.075 & 0.372 & 0.141 & -0.355 \\
\hline telcm & 0.015 & 0.037 & 0.051 & 0.151 & -0.007 & -0.109 \\
\hline toys & -0.015 & 0.168 & 0.082 & 0.134 & -0.057 & -0.217 \\
\hline trans & 0.015 & 0.088 & -0.064 & 0.222 & 0.252 & -0.341 \\
\hline txtls & 0.048 & 0.191 & -0.215 & 0.786 & 0.031 & -0.173 \\
\hline util & 0.033 & 0.011 & 0.163 & 0.148 & -0.219 & -0.041 \\
\hline whlsl & 0.075 & 0.080 & 0.105 & 0.184 & -0.018 & -0.087 \\
\hline
\end{tabular}


Table 9. Benchmark OLS regression estimates of $r_{t}^{\text {ind }}=\beta_{0}+\beta_{1} r_{t-1}^{\text {ind }}+\beta_{2} r_{t-1}^{\text {banks }}+\varepsilon_{t}^{\text {ind }}$ total sample (566 returns) from January 1970 to February 2017, and for two subsamples (79 returns), before and after the Dodd-Frank Act. Significant values are indicated with bold for levels of 10\% or lower.

\begin{tabular}{lcccccc}
\hline & Total sample & \multicolumn{3}{c}{$\begin{array}{c}\text { January2004- } \\
\text { July2010 }\end{array}$} & \multicolumn{3}{c}{$\begin{array}{c}\text { August2010- } \\
\text { February2017 }\end{array}$} \\
\hline & $\beta_{1}$ & $\beta_{2}$ & $\beta_{1}$ & $\beta_{2}$ & $\beta_{1}$ & $\beta_{2}$ \\
\hline Market & -0.003 & 0.074 & 0.170 & 0.108 & -0.026 & -0.099 \\
Size & -0.002 & $\mathbf{0 . 1 2 2}$ & -0.148 & $\mathbf{0 . 0 9 2}$ & $\mathbf{- 0 . 3 0 6}$ & 0.036 \\
Value & $\mathbf{0 . 1 6 6}$ & 0.021 & 0.197 & 0.039 & 0.196 & 0.016 \\
Momentum & 0.038 & $\mathbf{- 0 . 0 7 4}$ & 0.204 & -0.078 & 0.019 & 0.088 \\
Investment & $\mathbf{0 . 1 5 0}$ & 0.017 & 0.166 & 0.003 & 0.150 & 0.008 \\
Profitability & $\mathbf{0 . 1 4 3}$ & -0.023 & 0.123 & -0.014 & 0.087 & -0.034 \\
\hline
\end{tabular}


Table 10. Quantile regression autocorrelation coefficient $\beta_{1}(\tau)$ estimates of $r_{t}^{\text {ind }}=\beta_{0}(\tau)+$ $\beta_{1}(\tau) r_{t-1}^{\text {ind }}+\beta_{2}(\tau) r_{t-1}^{\text {banks }}+\varepsilon_{t}^{\text {ind }}$. Based on 566 monthly returns over the period from January 1970 to February 2017. Significant autocorrelations are indicated in boldface for significance levels of $10 \%$ or lower.

\begin{tabular}{|c|c|c|c|c|c|c|c|c|c|}
\hline$\tau$ & 0.1 & 0.2 & 0.3 & 0.4 & 0.5 & 0.6 & 0.7 & 0.8 & 0.9 \\
\hline aero & 0.134 & 0.061 & 0.057 & 0.056 & 0.033 & -0.006 & 0.007 & -0.014 & 0.107 \\
\hline agric & 0.042 & 0.015 & 0.021 & 0.003 & 0.022 & -0.049 & $-\mathbf{0 . 1 1 7}$ & -0.128 & -0.139 \\
\hline autos & 0.078 & -0.012 & 0.023 & 0.038 & 0.042 & 0.014 & -0.069 & -0.142 & -0.158 \\
\hline beer & 0.113 & -0.034 & -0.055 & -0.080 & -0.055 & -0.012 & -0.019 & -0.007 & -0.126 \\
\hline bldmt & -0.047 & 0.041 & 0.007 & -0.045 & -0.043 & -0.095 & -0.088 & -0.120 & -0.307 \\
\hline books & 0.150 & 0.205 & 0.163 & 0.106 & 0.134 & 0.092 & 0.092 & 0.095 & 0.033 \\
\hline boxes & 0.119 & 0.105 & 0.033 & 0.031 & 0.068 & 0.005 & -0.048 & -0.132 & -0.198 \\
\hline bussv & 0.089 & 0.143 & 0.134 & 0.114 & -0.017 & -0.032 & -0.028 & -0.057 & -0.153 \\
\hline chems & 0.144 & 0.040 & 0.031 & 0.005 & -0.022 & -0.133 & -0.163 & -0.219 & -0.187 \\
\hline chips & 0.027 & 0.130 & 0.064 & 0.013 & 0.028 & 0.043 & -0.027 & -0.046 & -0.071 \\
\hline clths & 0.314 & 0.234 & 0.198 & 0.165 & 0.110 & 0.058 & 0.047 & -0.022 & 0.010 \\
\hline cnstr & 0.040 & 0.015 & 0.020 & -0.025 & -0.046 & -0.003 & 0.026 & 0.033 & 0.115 \\
\hline coal & 0.134 & 0.013 & 0.015 & -0.075 & -0.088 & -0.100 & -0.043 & -0.011 & 0.130 \\
\hline comps & 0.138 & 0.090 & 0.039 & -0.041 & -0.022 & -0.071 & -0.018 & -0.037 & -0.097 \\
\hline drugs & 0.144 & 0.018 & 0.046 & 0.028 & -0.022 & -0.091 & $-\mathbf{- 0 . 1 3 5}$ & -0.200 & -0.219 \\
\hline elceq & -0.013 & -0.045 & 0.002 & 0.003 & -0.019 & -0.097 & $-\mathbf{0 . 1 7 2}$ & $-\mathbf{- 0 . 2 0 3}$ & -0.226 \\
\hline fabpr & 0.016 & 0.059 & 0.053 & 0.112 & 0.096 & 0.020 & -0.013 & -0.079 & -0.067 \\
\hline fin & 0.194 & 0.273 & 0.299 & 0.203 & 0.112 & 0.087 & -0.001 & 0.016 & 0.009 \\
\hline food & 0.209 & 0.087 & 0.017 & 0.025 & 0.063 & 0.011 & -0.042 & -0.100 & -0.194 \\
\hline fun & 0.135 & 0.036 & 0.088 & 0.075 & 0.110 & 0.087 & 0.097 & 0.074 & 0.074 \\
\hline gold & -0.003 & 0.001 & -0.018 & -0.057 & -0.061 & -0.035 & -0.030 & 0.021 & -0.004 \\
\hline guns & 0.066 & 0.034 & -0.029 & -0.001 & -0.040 & -0.067 & -0.067 & -0.085 & -0.119 \\
\hline hlth & 0.231 & 0.163 & 0.198 & 0.211 & 0.110 & 0.095 & 0.089 & 0.063 & 0.028 \\
\hline hshld & 0.240 & 0.136 & 0.058 & 0.032 & -0.001 & 0.004 & -0.040 & -0.086 & -0.204 \\
\hline insur & 0.178 & 0.092 & 0.083 & 0.144 & 0.076 & 0.015 & -0.019 & -0.092 & -0.083 \\
\hline labeq & 0.274 & 0.126 & 0.107 & 0.142 & 0.053 & -0.017 & -0.032 & -0.158 & -0.114 \\
\hline mach & 0.180 & 0.138 & 0.127 & 0.099 & 0.065 & -0.014 & -0.092 & -0.187 & -0.258 \\
\hline meals & 0.225 & 0.118 & 0.107 & 0.104 & 0.077 & 0.065 & 0.013 & 0.081 & 0.131 \\
\hline medeq & 0.064 & 0.149 & 0.110 & 0.040 & 0.029 & -0.053 & -0.056 & -0.114 & -0.148 \\
\hline mines & 0.051 & -0.010 & -0.056 & -0.025 & -0.039 & 0.000 & 0.030 & -0.020 & -0.085 \\
\hline oil & -0.023 & 0.009 & -0.004 & -0.002 & -0.033 & -0.115 & -0.152 & -0.095 & -0.142 \\
\hline other & 0.098 & 0.176 & 0.167 & 0.131 & 0.079 & 0.042 & 0.030 & -0.044 & -0.116 \\
\hline paper & -0.053 & -0.111 & -0.117 & -0.085 & -0.095 & -0.056 & -0.065 & -0.066 & -0.179 \\
\hline persv & 0.149 & 0.108 & 0.130 & 0.066 & 0.096 & 0.006 & -0.055 & -0.089 & -0.244 \\
\hline rlest & 0.086 & 0.082 & 0.101 & 0.125 & 0.176 & 0.104 & 0.085 & -0.024 & -0.110 \\
\hline rtail & 0.186 & 0.153 & 0.137 & 0.127 & 0.119 & 0.085 & 0.081 & 0.002 & 0.119 \\
\hline rubbr & 0.028 & -0.047 & -0.008 & -0.040 & -0.037 & -0.070 & -0.166 & $-\mathbf{0 . 1 4 8}$ & -0.107 \\
\hline ships & 0.115 & 0.105 & 0.128 & 0.089 & 0.058 & -0.007 & -0.081 & -0.086 & -0.189 \\
\hline smoke & 0.023 & -0.016 & 0.051 & -0.013 & 0.021 & 0.013 & 0.030 & 0.035 & 0.026 \\
\hline soda & -0.021 & -0.078 & -0.086 & 0.015 & 0.058 & 0.059 & 0.068 & 0.073 & 0.004 \\
\hline steel & 0.110 & 0.038 & -0.047 & -0.131 & -0.127 & -0.148 & -0.109 & -0.163 & -0.076 \\
\hline telcm & -0.086 & -0.057 & -0.060 & 0.039 & 0.110 & 0.152 & 0.097 & 0.050 & 0.045 \\
\hline toys & 0.008 & 0.006 & 0.051 & -0.044 & -0.010 & 0.006 & 0.050 & -0.020 & -0.146 \\
\hline $\operatorname{trans}$ & 0.109 & 0.064 & 0.137 & 0.039 & 0.040 & -0.029 & -0.010 & -0.111 & -0.236 \\
\hline txtls & 0.152 & 0.136 & 0.151 & 0.047 & 0.035 & -0.017 & -0.030 & -0.101 & -0.038 \\
\hline util & -0.068 & 0.034 & 0.005 & 0.034 & -0.017 & 0.032 & 0.079 & 0.107 & 0.094 \\
\hline whlsl & 0.154 & 0.203 & 0.165 & 0.120 & 0.077 & -0.008 & -0.013 & 0.008 & -0.153 \\
\hline
\end{tabular}


Table 11. Quantile cross-autocorrelation coefficients $\beta_{2}(\tau)$ estimates of $r_{t}^{\text {ind }}=\beta_{0}(\tau)+\beta_{1}(\tau) r_{t-1}^{\text {ind }}+\beta_{2}(\tau) r_{t-1}^{\text {banks }}+\varepsilon_{t}^{\text {ind }}$ based on 566 monthly returns over the period from January 1970 to February 2017. Significant cross-autocorrelations are indicated in boldface for significance levels of $10 \%$ or lower.

\begin{tabular}{|c|c|c|c|c|c|c|c|c|c|}
\hline & 0.1 & 0.2 & 0.3 & 0.4 & 0.5 & 0.6 & 0.7 & 0.8 & 0.9 \\
\hline aero & 0.214 & 0.225 & $\begin{array}{l}0.190 \\
\end{array}$ & 0.082 & 0.072 & 0.086 & 0.033 & 0.012 & -0.082 \\
\hline agric & 0.162 & 0.102 & 0.111 & 0.138 & 0.111 & 0.095 & 0.131 & 0.011 & -0.022 \\
\hline autos & 0.195 & 0.178 & 0.126 & 0.164 & 0.185 & 0.129 & 0.114 & 0.142 & 0.111 \\
\hline beer & 0.037 & 0.092 & $\mathbf{0 . 1 2 4}$ & 0.089 & 0.057 & 0.022 & 0.042 & 0.051 & 0.067 \\
\hline bldmt & 0.388 & 0.228 & 0.213 & 0.224 & 0.190 & 0.162 & 0.086 & 0.051 & 0.218 \\
\hline books & 0.179 & 0.083 & 0.090 & 0.086 & 0.058 & 0.014 & 0.030 & -0.044 & -0.030 \\
\hline boxes & 0.089 & 0.028 & 0.052 & 0.032 & -0.016 & 0.043 & 0.060 & 0.088 & 0.045 \\
\hline bussv & 0.216 & 0.134 & 0.071 & 0.097 & 0.155 & 0.129 & 0.088 & 0.023 & 0.029 \\
\hline chems & 0.071 & 0.159 & 0.063 & 0.037 & 0.054 & 0.103 & 0.111 & 0.132 & -0.029 \\
\hline chips & 0.168 & 0.089 & 0.124 & 0.165 & 0.090 & 0.035 & -0.008 & 0.052 & 0.081 \\
\hline clths & 0.014 & 0.088 & 0.088 & 0.046 & 0.055 & 0.041 & 0.010 & 0.064 & 0.047 \\
\hline cnstr & 0.356 & 0.293 & 0.226 & 0.222 & 0.173 & 0.186 & 0.099 & 0.047 & -0.005 \\
\hline coal & 0.150 & 0.136 & 0.044 & 0.103 & 0.068 & 0.010 & -0.012 & -0.178 & -0.268 \\
\hline comps & 0.034 & 0.073 & 0.062 & 0.122 & 0.102 & 0.128 & 0.013 & 0.013 & 0.095 \\
\hline drugs & 0.009 & 0.065 & 0.077 & 0.057 & 0.048 & 0.047 & 0.009 & 0.012 & 0.021 \\
\hline elceq & 0.317 & 0.267 & 0.108 & 0.027 & 0.055 & 0.130 & 0.111 & 0.168 & 0.110 \\
\hline fabpr & 0.395 & 0.302 & 0.244 & 0.152 & 0.104 & 0.104 & 0.111 & 0.168 & 0.114 \\
\hline fin & 0.159 & 0.007 & -0.046 & 0.032 & 0.055 & 0.029 & 0.016 & -0.006 & -0.014 \\
\hline food & 0.013 & 0.047 & 0.072 & 0.050 & 0.046 & 0.042 & 0.041 & 0.059 & 0.060 \\
\hline fun & 0.242 & 0.147 & 0.059 & 0.038 & 0.070 & 0.053 & 0.016 & -0.053 & -0.057 \\
\hline gold & 0.085 & 0.034 & 0.145 & 0.027 & 0.073 & 0.006 & 0.032 & 0.012 & -0.238 \\
\hline guns & 0.216 & 0.129 & 0.172 & 0.148 & 0.118 & 0.090 & 0.057 & 0.068 & 0.072 \\
\hline hlth & 0.145 & 0.234 & 0.210 & 0.106 & 0.146 & 0.133 & 0.100 & 0.094 & -0.065 \\
\hline hshld & 0.128 & 0.076 & 0.068 & 0.053 & 0.024 & 0.081 & 0.041 & 0.069 & 0.134 \\
\hline insur & 0.119 & 0.154 & 0.112 & 0.025 & 0.021 & 0.000 & 0.015 & 0.023 & -0.041 \\
\hline labeq & 0.053 & 0.140 & 0.167 & 0.084 & 0.073 & 0.078 & 0.021 & 0.065 & 0.081 \\
\hline mach & 0.187 & 0.177 & 0.134 & 0.052 & 0.074 & 0.093 & 0.106 & 0.114 & 0.106 \\
\hline meals & 0.145 & 0.108 & 0.136 & 0.117 & 0.030 & 0.034 & 0.033 & -0.027 & -0.117 \\
\hline medeq & 0.106 & 0.015 & 0.050 & 0.103 & 0.067 & 0.104 & 0.048 & 0.066 & 0.099 \\
\hline mines & 0.229 & 0.171 & 0.099 & 0.078 & 0.124 & 0.110 & 0.010 & 0.046 & -0.013 \\
\hline oil & 0.229 & 0.093 & $\mathbf{0 . 0 8 3}$ & 0.070 & 0.076 & 0.059 & 0.026 & -0.057 & -0.110 \\
\hline other & 0.252 & 0.099 & 0.016 & 0.046 & 0.095 & 0.090 & 0.015 & 0.074 & 0.012 \\
\hline paper & 0.313 & 0.331 & 0.245 & 0.171 & 0.114 & 0.096 & 0.063 & -0.012 & 0.034 \\
\hline persv & 0.230 & 0.160 & 0.087 & 0.079 & -0.002 & 0.046 & 0.057 & 0.106 & 0.136 \\
\hline rlest & 0.420 & 0.347 & 0.252 & 0.187 & 0.165 & 0.159 & 0.126 & 0.253 & 0.228 \\
\hline rtail & 0.037 & 0.078 & 0.010 & -0.044 & -0.037 & -0.021 & -0.031 & -0.004 & -0.053 \\
\hline rubbr & 0.395 & $\mathbf{0 . 3 3 0}$ & 0.226 & 0.202 & 0.170 & 0.137 & 0.207 & 0.195 & 0.107 \\
\hline ships & 0.293 & 0.262 & 0.121 & 0.112 & 0.102 & 0.068 & 0.042 & 0.014 & -0.057 \\
\hline smoke & 0.083 & 0.008 & 0.002 & 0.035 & 0.007 & 0.018 & -0.014 & -0.001 & 0.055 \\
\hline soda & 0.194 & 0.136 & 0.062 & 0.033 & 0.031 & 0.009 & -0.019 & -0.052 & -0.083 \\
\hline steel & 0.285 & 0.260 & 0.222 & 0.226 & 0.140 & 0.145 & 0.093 & 0.056 & -0.023 \\
\hline telcm & 0.226 & 0.187 & 0.160 & 0.059 & -0.015 & -0.041 & -0.032 & -0.045 & -0.119 \\
\hline toys & 0.261 & 0.276 & 0.170 & 0.200 & $\mathbf{0 . 1 5 0}$ & 0.098 & 0.025 & 0.023 & 0.044 \\
\hline trans & 0.138 & 0.235 & 0.091 & 0.075 & 0.018 & 0.033 & 0.010 & 0.023 & 0.111 \\
\hline txtls & 0.255 & 0.211 & 0.196 & 0.171 & 0.138 & 0.145 & 0.087 & 0.127 & 0.043 \\
\hline util & 0.156 & 0.057 & 0.043 & 0.028 & 0.020 & -0.009 & -0.057 & -0.086 & -0.105 \\
\hline whlsl & 0.257 & 0.151 & 0.113 & 0.143 & 0.098 & 0.050 & 0.028 & -0.011 & 0.125 \\
\hline
\end{tabular}


Table 12. Quantile regression cross- and autocorrelation coefficient estimates of the model $r_{t}^{\text {factor }}=\beta_{0}(\tau)+\beta_{1}(\tau) r_{t-1}^{\text {factor }}+\beta_{2}(\tau) r_{t-1}^{\text {banks }}+\varepsilon_{t}^{\text {factor }}$. Based on 566 monthly returns over the period January 1970 to February 2017. Significant correlations are indicated in boldface for significance levels of $10 \%$ or lower.

\begin{tabular}{lrrrrrrrrr}
\hline \multicolumn{1}{c}{$\tau$} & 0.1 & 0.2 & 0.3 & 0.4 & 0.5 & 0.6 & 0.7 & 0.8 & 0.9 \\
\hline Autocorrelation & & & & & & & & & \\
market & $\mathbf{0 . 1 6 8}$ & 0.088 & 0.067 & 0.043 & -0.051 & -0.163 & -0.114 & -0.092 & -0.160 \\
size & 0.052 & 0.127 & 0.095 & 0.076 & 0.058 & 0.078 & -0.006 & -0.035 & -0.052 \\
value & 0.135 & 0.175 & $\mathbf{0 . 2 2 2}$ & $\mathbf{0 . 2 0 1}$ & $\mathbf{0 . 1 8 7}$ & $\mathbf{0 . 1 6 8}$ & $\mathbf{0 . 2 0 9}$ & $\mathbf{0 . 2 2 4}$ & $\mathbf{0 . 2 4 6}$ \\
momentum & 0.069 & -0.020 & 0.031 & 0.048 & 0.069 & 0.068 & 0.078 & 0.072 & 0.028 \\
investment & 0.017 & 0.098 & $\mathbf{0 . 1 6 5}$ & $\mathbf{0 . 2 0 1}$ & $\mathbf{0 . 1 7 7}$ & $\mathbf{0 . 2 3 0}$ & $\mathbf{0 . 2 6 2}$ & $\mathbf{0 . 2 4 5}$ & $\mathbf{0 . 2 3 7}$ \\
profitability & $\mathbf{0 . 1 9 7}$ & 0.129 & 0.104 & $\mathbf{0 . 1 5 3}$ & $\mathbf{0 . 1 7 6}$ & $\mathbf{0 . 1 7 1}$ & $\mathbf{0 . 1 6 6}$ & $\mathbf{0 . 1 6 6}$ & $\mathbf{0 . 2 0 7}$ \\
& & & & & & & & & \\
Cross- & & & & & & & & & \\
autocorrelation & & & & & & & & & \\
market & $\mathbf{0 . 1 4 8}$ & $\mathbf{0 . 1 5 5}$ & 0.098 & 0.111 & 0.099 & $\mathbf{0 . 1 3 2}$ & 0.076 & 0.028 & 0.033 \\
size & $\mathbf{0 . 0 9 1}$ & $\mathbf{0 . 1 1 4}$ & $\mathbf{0 . 1 1 8}$ & $\mathbf{0 . 0 9 6}$ & $\mathbf{0 . 0 8 1}$ & $\mathbf{0 . 0 8 9}$ & $\mathbf{0 . 1 1 4}$ & $\mathbf{0 . 1 1 7}$ & $\mathbf{0 . 1 2 1}$ \\
value & $\mathbf{0 . 0 5 2}$ & 0.032 & 0.020 & 0.013 & 0.015 & 0.027 & 0.022 & 0.007 & -0.007 \\
momentum & -0.007 & -0.011 & 0.013 & -0.006 & -0.049 & $\mathbf{- 0 . 0 6 6}$ & $\mathbf{- 0 . 0 5 1}$ & -0.042 & $\mathbf{- 0 . 1 1 4}$ \\
investment & -0.016 & 0.014 & $\mathbf{0 . 0 4 0}$ & $\mathbf{0 . 0 3 4}$ & 0.018 & 0.014 & 0.019 & 0.020 & $\mathbf{0 . 0 4 0}$ \\
profitability & -0.009 & -0.001 & -0.013 & -0.013 & -0.009 & -0.006 & -0.013 & -0.019 & -0.036 \\
\hline
\end{tabular}


Table 13. Quantile regression autocorrelation coefficient $\beta_{1}(\tau)$ estimates of $r_{t}^{\text {ind }}=\beta_{0}(\tau)+$ $\beta_{1}(\tau) r_{t-1}^{\text {ind }}+\beta_{2}(\tau) r_{t-1}^{\text {banks }}+\varepsilon_{t}^{\text {ind }}$. Based on 79 monthly returns over the period from January 2004 to July 2010. Significant autocorrelations are indicated in boldface for significance levels of $10 \%$ or lower.

\begin{tabular}{|c|c|c|c|c|c|c|c|c|c|}
\hline$\tau$ & 0.1 & 0.2 & 0.3 & 0.4 & 0.5 & 0.6 & 0.7 & 0.8 & 0.9 \\
\hline aero & 0.290 & 0.054 & -0.023 & -0.200 & -0.273 & -0.306 & -0.434 & -0.534 & -0.784 \\
\hline agric & 0.475 & 0.421 & 0.338 & 0.242 & 0.057 & 0.049 & 0.195 & 0.218 & 0.012 \\
\hline autos & 0.093 & -0.081 & -0.091 & -0.156 & -0.015 & 0.011 & -0.048 & -0.120 & -0.169 \\
\hline beer & 0.079 & -0.257 & -0.185 & -0.191 & -0.232 & -0.082 & -0.056 & -0.034 & -0.233 \\
\hline bldmt & -0.188 & -0.368 & -0.132 & -0.087 & -0.021 & 0.008 & -0.050 & 0.059 & -0.173 \\
\hline books & 0.093 & 0.086 & 0.165 & 0.285 & 0.231 & 0.189 & 0.151 & 0.084 & -0.067 \\
\hline boxes & -0.051 & -0.033 & -0.130 & -0.191 & -0.027 & -0.003 & -0.082 & -0.056 & -0.057 \\
\hline bussv & 0.004 & 0.119 & 0.071 & 0.145 & 0.019 & 0.028 & 0.141 & 0.194 & 0.163 \\
\hline chems & 0.600 & 0.286 & 0.083 & 0.028 & -0.124 & -0.097 & -0.110 & -0.214 & -0.751 \\
\hline chips & 0.463 & 0.326 & 0.110 & -0.065 & -0.158 & -0.158 & -0.236 & -0.284 & -0.227 \\
\hline clths & 0.189 & 0.122 & -0.114 & -0.229 & -0.237 & -0.218 & -0.156 & -0.160 & -0.138 \\
\hline cnstr & 0.023 & -0.185 & -0.201 & -0.055 & -0.088 & -0.105 & -0.034 & 0.130 & 0.173 \\
\hline coal & 0.193 & 0.199 & 0.118 & -0.012 & 0.045 & 0.018 & 0.147 & 0.319 & 0.112 \\
\hline comps & 0.015 & 0.186 & 0.009 & 0.076 & 0.139 & 0.094 & 0.129 & 0.012 & 0.031 \\
\hline drugs & -0.087 & 0.047 & 0.088 & 0.107 & -0.010 & -0.115 & -0.062 & -0.208 & $-\mathbf{0 . 3 9 8}$ \\
\hline elceq & -0.226 & -0.153 & -0.131 & -0.067 & -0.101 & -0.411 & -0.311 & -0.355 & -0.144 \\
\hline fabpr & 0.143 & -0.020 & -0.010 & -0.042 & 0.133 & -0.093 & -0.158 & -0.259 & -0.227 \\
\hline fin & 0.644 & 0.813 & 0.536 & 0.345 & 0.219 & 0.244 & 0.247 & 0.166 & 0.458 \\
\hline food & -0.212 & -0.131 & -0.163 & -0.218 & -0.166 & -0.128 & -0.058 & -0.036 & 0.085 \\
\hline fun & 0.011 & 0.026 & -0.099 & -0.046 & -0.082 & -0.053 & -0.121 & -0.204 & -0.620 \\
\hline gold & -0.047 & -0.209 & -0.329 & -0.245 & -0.332 & -0.290 & -0.150 & -0.299 & 0.078 \\
\hline guns & -0.231 & -0.121 & -0.003 & -0.046 & -0.040 & -0.378 & -0.460 & -0.319 & $\mathbf{- 0 . 5 5 7}$ \\
\hline hlth & 0.166 & 0.165 & -0.064 & -0.169 & -0.257 & -0.224 & -0.192 & -0.248 & -0.247 \\
\hline hshld & -0.048 & -0.123 & -0.079 & 0.009 & -0.037 & -0.103 & -0.212 & -0.235 & -0.049 \\
\hline insur & 0.234 & -0.116 & -0.003 & 0.064 & 0.207 & 0.250 & 0.239 & 0.023 & -0.227 \\
\hline labeq & 0.081 & 0.067 & 0.108 & -0.039 & -0.025 & -0.027 & -0.122 & -0.338 & -0.279 \\
\hline mach & 0.315 & 0.013 & 0.096 & 0.010 & -0.096 & -0.201 & -0.305 & -0.307 & -0.657 \\
\hline meals & -0.148 & -0.263 & -0.261 & -0.055 & -0.095 & -0.052 & -0.147 & 0.041 & 0.096 \\
\hline medeq & 0.477 & 0.119 & -0.051 & 0.070 & -0.046 & -0.262 & -0.389 & -0.247 & -0.206 \\
\hline mines & 0.552 & 0.103 & -0.068 & -0.091 & -0.116 & -0.204 & & -0.115 & -0.177 \\
\hline oil & -0.173 & -0.032 & -0.083 & -0.201 & -0 . & -0 . & -0 . & -0.153 & -0.215 \\
\hline other & -0.085 & 0.086 & 0.233 & 0.308 & 0.169 & -0.026 & -0.343 & -0.653 & -0.518 \\
\hline paper & 0.056 & -0.246 & -0.221 & -0.188 & -0.079 & 0.037 & 0.028 & 0.062 & 0.062 \\
\hline persv & 0.025 & -0.048 & 0.038 & -0.044 & -0.021 & -0.140 & -0.274 & -0.207 & -0.417 \\
\hline rlest & -0.041 & -0.027 & -0.078 & -0.134 & -0.045 & -0.157 & -0.296 & -0.300 & -0.364 \\
\hline rtail & -0.110 & 0.047 & 0.027 & 0.015 & 0.096 & 0.208 & 0.080 & 0.244 & 0.080 \\
\hline rubbr & -0.068 & -0.108 & -0.304 & -0.220 & -0.045 & 0.043 & -0.080 & -0.219 & -0.121 \\
\hline ships & -0.078 & -0.050 & -0.088 & -0.263 & & -0.227 & & & -0.255 \\
\hline smoke & 0.089 & -0.316 & -0.432 & $-\mathbf{0 . 3 5 7}$ & -0.371 & -0.242 & -0.160 & -0.077 & 0.006 \\
\hline soda & 0.080 & -0.020 & -0.002 & -0.008 & -0.026 & 0.073 & 0.122 & 0.156 & 0.077 \\
\hline steel & 0.215 & 0.237 & -0.002 & -0.135 & -0.209 & -0.303 & -0.319 & -0.301 & -0.263 \\
\hline telcm & -0.014 & -0.204 & -0.204 & -0.191 & -0.045 & 0.048 & 0.149 & 0.098 & 0.079 \\
\hline toys & -0.079 & 0.134 & 0.337 & 0.235 & 0.029 & -0.093 & 0.026 & 0.099 & -0.014 \\
\hline $\operatorname{trans}$ & -0.031 & -0.177 & -0.149 & -0.038 & -0.063 & -0.029 & 0.004 & -0.030 & -0.196 \\
\hline txtls & -0.262 & -0.332 & -0.316 & -0.355 & -0.384 & -0.354 & -0.340 & -0.252 & -0.365 \\
\hline util & 0.595 & 0.309 & 0.301 & 0.200 & 0.221 & 0.163 & 0.044 & 0.183 & 0.146 \\
\hline whlsl & 0.084 & 0.175 & 0.055 & 0.023 & -0.079 & -0.303 & -0.271 & -0.091 & -0.094 \\
\hline
\end{tabular}


Table 14. Quantile cross-autocorrelation coefficients $\beta_{2}(\tau)$ estimates of $r_{t}^{\text {ind }}=\beta_{0}(\tau)+$ $\beta_{1}(\tau) r_{t-1}^{\text {ind }}+\beta_{2}(\tau) r_{t-1}^{\text {banks }}+\varepsilon_{t}^{\text {ind }}$ based on 79 monthly returns over the period from January 2004 to July 2010. Significant cross-autocorrelations are indicated in boldface for significance levels of $10 \%$ or lower

\begin{tabular}{|c|c|c|c|c|c|c|c|c|c|}
\hline$\tau$ & 0.1 & 0.2 & 0.3 & 0.4 & 0.5 & 0.6 & 0.7 & 0.8 & 0.9 \\
\hline aero & 0.409 & 0.538 & 0.504 & 0.488 & 0.524 & 0.421 & 0.571 & 0.590 & 0.813 \\
\hline agric & -0.072 & -0.018 & 0.007 & -0.004 & 0.059 & 0.025 & -0.306 & -0.267 & -0.379 \\
\hline autos & 0.025 & 0.344 & 0.299 & 0.361 & 0.380 & 0.387 & $\mathbf{0 . 3 8 0}$ & 0.485 & -0.133 \\
\hline beer & 0.151 & 0.152 & 0.049 & 0.058 & 0.020 & -0.029 & -0.014 & 0.015 & 0.141 \\
\hline bldmt & 0.440 & 0.695 & 0.362 & 0.350 & 0.291 & 0.193 & 0.213 & 0.032 & 0.173 \\
\hline books & 0.189 & 0.289 & 0.236 & 0.170 & 0.146 & 0.134 & 0.185 & 0.279 & 0.407 \\
\hline boxes & 0.180 & 0.348 & 0.287 & 0.261 & 0.220 & 0.176 & 0.143 & 0.096 & -0.009 \\
\hline bussv & 0.198 & 0.272 & 0.236 & 0.105 & 0.166 & 0.171 & 0.065 & -0.006 & -0.106 \\
\hline chems & -0.110 & 0.176 & 0.226 & $\mathbf{0 . 3 0 7}$ & 0.372 & 0.313 & 0.284 & 0.293 & 0.616 \\
\hline chips & -0.110 & 0.210 & 0.243 & 0.265 & 0.250 & 0.150 & 0.186 & 0.222 & 0.250 \\
\hline clths & 0.222 & 0.239 & 0.339 & 0.436 & 0.485 & 0.504 & 0.441 & 0.261 & 0.400 \\
\hline cnstr & 0.348 & 0.357 & 0.430 & 0.345 & 0.289 & 0.433 & 0.489 & -0.073 & 0.009 \\
\hline coal & 0.654 & 0.681 & 0.270 & 0.351 & 0.370 & 0.558 & 0.531 & 0.465 & 0.699 \\
\hline comps & 0.438 & 0.089 & 0.285 & 0.233 & 0.227 & 0.205 & 0.171 & 0.235 & 0.049 \\
\hline drugs & 0.129 & 0.067 & 0.176 & 0.095 & 0.139 & 0.060 & 0.014 & -0.087 & 0.012 \\
\hline elceq & 0.533 & 0.435 & 0.273 & 0.106 & 0.162 & 0.405 & 0.353 & 0.242 & 0.108 \\
\hline fabpr & 0.195 & 0.346 & 0.317 & 0.355 & 0.195 & 0.375 & 0.288 & 0.358 & 0.327 \\
\hline fin & 0.198 & -0.222 & -0.165 & -0.030 & 0.059 & 0.115 & 0.159 & 0.032 & -0.168 \\
\hline food & 0.420 & 0.341 & 0.240 & 0.222 & 0.120 & 0.131 & 0.067 & 0.040 & 0.029 \\
\hline fun & 0.895 & 0.654 & 0.652 & 0.585 & 0.565 & 0.437 & 0.532 & 0.556 & 1.088 \\
\hline gold & -0.220 & -0.065 & -0.184 & -0.203 & -0.148 & -0.410 & -0.188 & -0.198 & -0.275 \\
\hline guns & 0.559 & 0.482 & 0.418 & 0.338 & 0.254 & 0.441 & 0.384 & 0.279 & 0.418 \\
\hline hlth & 0.325 & 0.288 & 0.336 & 0.367 & 0.392 & 0.359 & 0.214 & 0.215 & 0.189 \\
\hline hshld & 0.288 & 0.368 & 0.192 & 0.186 & 0.197 & 0.205 & 0.198 & 0.167 & 0.109 \\
\hline insur & 0.348 & 0.356 & 0.288 & 0.215 & 0.059 & 0.016 & -0.138 & 0.063 & 0.222 \\
\hline labeq & 0.074 & 0.273 & 0.231 & 0.312 & 0.327 & 0.264 & 0.352 & 0.450 & 0.263 \\
\hline mach & 0.226 & 0.349 & 0.239 & 0.229 & 0.325 & 0.267 & $\mathbf{0 . 3 3 1}$ & 0.269 & 0.416 \\
\hline meals & 0.271 & 0.423 & 0.478 & 0.292 & 0.294 & 0.150 & 0.168 & 0.053 & -0.129 \\
\hline medeq & 0.328 & 0.382 & 0.315 & 0.245 & 0.159 & 0.229 & 0.252 & 0.187 & 0.155 \\
\hline mines & 0.021 & 0.313 & 0.371 & 0.614 & 0.597 & 0.341 & 0.431 & 0.014 & 0.031 \\
\hline oil & 0.305 & 0.341 & 0.416 & 0.307 & 0.284 & 0.367 & 0.273 & 0.260 & 0.188 \\
\hline other & 0.585 & 0.329 & 0.240 & 0.022 & 0.151 & 0.272 & 0.506 & 0.612 & 0.505 \\
\hline paper & 0.344 & 0.503 & 0.464 & 0.433 & 0.363 & 0.246 & 0.274 & -0.041 & -0.189 \\
\hline persv & 0.150 & 0.227 & 0.316 & 0.278 & 0.210 & 0.240 & 0.255 & 0.177 & 0.109 \\
\hline rlest & 0.573 & 0.662 & 0.665 & 0.582 & 0.579 & 0.588 & 0.758 & 0.589 & 0.659 \\
\hline rtail & 0.209 & 0.271 & 0.167 & 0.030 & 0.041 & -0.035 & 0.048 & -0.108 & 0.032 \\
\hline rubbr & 0.563 & 0.562 & 0.720 & 0.549 & 0.425 & 0.284 & 0.269 & 0.326 & 0.172 \\
\hline ships & 0.594 & 0.658 & 0.558 & 0.688 & 0.695 & 0.550 & 0.335 & 0.440 & 0.232 \\
\hline smoke & 0.305 & 0.245 & 0.318 & 0.250 & 0.189 & 0.124 & 0.126 & 0.147 & 0.127 \\
\hline soda & 0.314 & 0.170 & 0.094 & 0.123 & 0.189 & 0.205 & 0.167 & 0.004 & 0.036 \\
\hline steel & 0.331 & 0.316 & 0.590 & 0.648 & 0.692 & 0.654 & 0.592 & 0.628 & 0.271 \\
\hline telcm & 0.346 & 0.286 & 0.288 & 0.303 & 0.259 & 0.203 & 0.161 & 0.196 & 0.092 \\
\hline toys & 0.437 & 0.255 & 0.029 & 0.015 & 0.229 & 0.136 & 0.015 & -0.115 & -0.138 \\
\hline trans & 0.286 & 0.449 & 0.397 & 0.216 & 0.227 & 0.091 & 0.034 & -0.002 & 0.020 \\
\hline txtls & 0.932 & 0.928 & 0.718 & 0.776 & 0.793 & 0.806 & 0.646 & 0.568 & 0.482 \\
\hline util & 0.273 & 0.249 & 0.194 & 0.147 & 0.047 & 0.036 & 0.091 & 0.033 & -0.008 \\
\hline whlsl & 0.346 & 0.226 & 0.276 & 0.311 & 0.280 & $\mathbf{0 . 3 5 5}$ & 0.295 & 0.162 & 0.187 \\
\hline
\end{tabular}


Table 15. Quantile regression cross- and autocorrelation coefficient estimates of the model $r_{t}^{\text {factor }}=\beta_{0}(\tau)+\beta_{1}(\tau) r_{t-1}^{\text {factor }}+\beta_{2}(\tau) r_{t-1}^{\text {banks }}+\varepsilon_{t}^{\text {factor }}$. Based on 79 monthly returns over the period January 2004 to July 2010. Significant correlations are indicated in boldface for significance levels of $10 \%$ or lower.

\begin{tabular}{lrrrrrrrrr}
\hline \multicolumn{1}{c}{$\tau$} & 0.1 & 0.2 & 0.3 & 0.4 & 0.5 & 0.6 & 0.7 & 0.8 & 0.9 \\
\hline Autocorrelation & & & & & & & & & \\
market & 0.194 & 0.068 & 0.091 & -0.117 & 0.169 & 0.050 & -0.137 & -0.111 & -0.409 \\
size & -0.028 & -0.114 & -0.199 & -0.149 & -0.062 & -0.136 & -0.181 & -0.091 & -0.392 \\
value & -0.073 & 0.151 & 0.306 & 0.194 & 0.178 & 0.143 & 0.298 & 0.207 & 0.379 \\
momentum & $\mathbf{0 . 3 3 2}$ & $\mathbf{0 . 2 8 7}$ & $\mathbf{0 . 2 2 3}$ & 0.027 & -0.086 & -0.070 & -0.021 & 0.055 & -0.148 \\
investment & 0.124 & -0.001 & -0.107 & -0.074 & -0.023 & 0.047 & 0.239 & $\mathbf{0 . 3 9 9}$ & $\mathbf{0 . 5 1 4}$ \\
profitability & -0.062 & -0.210 & 0.008 & 0.243 & 0.185 & 0.104 & 0.034 & 0.118 & 0.078 \\
& & & & & & & & & \\
Cross- & & & & & & & & & \\
autocorrelation & & & & & & & & & \\
market & $\mathbf{0 . 2 4 7}$ & $\mathbf{0 . 2 6 9}$ & $\mathbf{0 . 2 9 2}$ & $\mathbf{0 . 3 2 5}$ & 0.129 & 0.168 & 0.223 & 0.172 & 0.244 \\
size & 0.030 & 0.100 & 0.141 & 0.062 & 0.073 & $\mathbf{0 . 1 2 0}$ & $\mathbf{0 . 1 1 0}$ & $\mathbf{0 . 1 3 3}$ & 0.122 \\
value & $\mathbf{0 . 1 9 5}$ & 0.133 & -0.035 & -0.016 & 0.011 & 0.011 & -0.031 & 0.046 & -0.165 \\
momentum & 0.209 & 0.017 & -0.129 & -0.067 & -0.129 & -0.118 & -0.068 & -0.035 & -0.175 \\
investment & 0.002 & 0.011 & 0.019 & 0.030 & 0.034 & 0.007 & -0.009 & -0.007 & -0.025 \\
profitability & -0.033 & -0.038 & -0.035 & 0.041 & 0.020 & -0.002 & -0.028 & -0.021 & -0.085 \\
\hline
\end{tabular}


Table 16. Quantile regression autocorrelation coefficient $\beta_{1}(\tau)$ estimates of $r_{t}^{\text {ind }}=\beta_{0}(\tau)+$ $\beta_{1}(\tau) r_{t-1}^{\text {ind }}+\beta_{2}(\tau) r_{t-1}^{\text {banks }}+\varepsilon_{t}^{\text {ind }}$. Based on 79 monthly returns over the period from August 2010 to February 2017. Significant autocorrelations are indicated in boldface for significance levels of $10 \%$ or lower.

\begin{tabular}{|c|c|c|c|c|c|c|c|c|c|}
\hline$\tau$ & 0.1 & 0.2 & 0.3 & 0.4 & 0.5 & 0.6 & 0.7 & 0.8 & 0.9 \\
\hline aero & 0.108 & 0.150 & 0.088 & -0.073 & 0.114 & 0.164 & 0.172 & 0.088 & 0.016 \\
\hline agric & -0.256 & -0.164 & -0.257 & -0.208 & -0.123 & -0.091 & -0.132 & -0.220 & -0.358 \\
\hline autos & -0.289 & 0.440 & 0.309 & 0.149 & 0.104 & 0.190 & 0.248 & 0.321 & 0.033 \\
\hline beer & -0.543 & -0.386 & -0.233 & -0.062 & -0.092 & -0.064 & -0.144 & -0.196 & 0.002 \\
\hline bldmt & 0.015 & 0.211 & 0.248 & 0.173 & -0.030 & -0.116 & -0.159 & -0.197 & -0.009 \\
\hline books & -0.080 & 0.114 & 0.098 & -0.095 & -0.174 & -0.221 & $-\mathbf{0 . 3 3 4}$ & -0.247 & -0.215 \\
\hline boxes & -0.032 & 0.021 & 0.018 & -0.055 & -0.218 & -0.146 & -0.121 & -0.140 & -0.107 \\
\hline bussv & -0.253 & -0.129 & -0.183 & -0.174 & -0.126 & -0.125 & -0.172 & -0.194 & 0.023 \\
\hline chems & 0.341 & 0.284 & 0.154 & 0.171 & 0.116 & -0.052 & -0.058 & -0.127 & -0.221 \\
\hline chips & 0.415 & 0.303 & 0.159 & 0.169 & 0.056 & -0.003 & -0.109 & -0.180 & -0.150 \\
\hline clths & 0.030 & 0.164 & 0.047 & -0.091 & -0.069 & -0.096 & -0.066 & 0.055 & -0.059 \\
\hline cnstr & 0.063 & 0.059 & 0.063 & -0.155 & -0.269 & -0.162 & -0.103 & 0.011 & -0.063 \\
\hline coal & 0.239 & 0.187 & -0.053 & -0.284 & -0.216 & -0.210 & -0.111 & -0.042 & -0.025 \\
\hline comps & 0.027 & -0.140 & -0.142 & -0.081 & -0.036 & -0.128 & 0.084 & 0.073 & 0.125 \\
\hline drugs & -0.242 & -0.102 & -0.012 & -0.079 & -0.090 & -0.040 & -0.071 & -0.203 & -0.239 \\
\hline elceq & -0.054 & 0.183 & 0.206 & 0.221 & 0.025 & 0.020 & 0.031 & -0.152 & -0.218 \\
\hline fabpr & -0.254 & -0.059 & 0.003 & 0.179 & 0.246 & 0.244 & 0.059 & 0.006 & 0.181 \\
\hline fin & 0.759 & 0.386 & 0.254 & 0.192 & 0.002 & 0.004 & -0.165 & -0.302 & -0.600 \\
\hline food & -0.089 & -0.136 & -0.191 & -0.358 & -0.422 & -0.326 & -0.355 & -0.282 & -0.154 \\
\hline fun & -0.011 & 0.086 & 0.041 & 0.048 & 0.026 & -0.256 & -0.192 & -0.146 & -0.037 \\
\hline gold & 0.093 & -0.182 & -0.223 & -0.073 & -0.103 & -0.131 & -0.107 & 0.015 & -0.167 \\
\hline guns & 0.002 & 0.097 & 0.161 & 0.121 & 0.093 & -0.009 & 0.033 & -0.005 & 0.065 \\
\hline hlth & 0.033 & 0.313 & 0.265 & 0.263 & 0.101 & 0.089 & 0.019 & 0.167 & 0.209 \\
\hline hshld & 0.217 & 0.265 & 0.041 & -0.002 & 0.171 & -0.030 & -0.012 & -0.008 & -0.301 \\
\hline insur & 0.556 & 0.083 & -0.145 & -0.186 & -0.384 & -0.404 & -0.541 & -0.280 & -0.654 \\
\hline labeq & 0.525 & 0.501 & 0.376 & 0.244 & 0.225 & -0.032 & 0.033 & 0.019 & 0.027 \\
\hline mach & -0.180 & 0.015 & 0.098 & 0.211 & 0.178 & 0.213 & 0.095 & -0.044 & -0.261 \\
\hline meals & 0.000 & 0.313 & 0.172 & 0.207 & 0.105 & 177 & 0.119 & 0.057 & -0.052 \\
\hline medeq & -0.075 & 0.119 & -0.016 & -0.093 & -0.085 & -0.107 & $-0 .($ & -0.170 & -0.511 \\
\hline mines & 0.151 & 0.076 & -0.021 & -0.062 & -0.002 & -0.160 & -0.038 & 0.074 & -0.120 \\
\hline oil & 0.508 & 0.043 & 0.197 & 0.261 & 0.059 & 0.078 & 0.014 & 0.110 & -0.060 \\
\hline other & -0.076 & 0.037 & 0.112 & -0.055 & -0.140 & -0.217 & -0.019 & -0.058 & -0.203 \\
\hline paper & -0.129 & 0.330 & 0.274 & 0.073 & -0.077 & -0.048 & -0.109 & -0.037 & -0.080 \\
\hline persv & -0.097 & -0.115 & -0.145 & -0.082 & -0.147 & -0.250 & -0.153 & -0.365 & -0.616 \\
\hline rlest & 0.047 & 0.132 & 0.066 & 0.043 & 0.115 & 0.084 & -0.181 & -0.088 & -0.442 \\
\hline rtail & -0.525 & -0.191 & -0.077 & -0.049 & 0.069 & -0.018 & -0.067 & -0.118 & -0.244 \\
\hline rubbr & -0.579 & -0.149 & 0.004 & -0.179 & -0.174 & -0.082 & -0.098 & -0.189 & -0.319 \\
\hline ships & 0.062 & 0.176 & 0.165 & 0.205 & 0.211 & 0.046 & 0.208 & 0.275 & -0.057 \\
\hline smoke & -0.565 & -0.451 & -0.362 & -0.332 & -0.139 & -0.125 & -0.116 & -0.037 & -0.286 \\
\hline soda & -0.420 & -0.358 & -0.256 & -0.129 & -0.045 & 0.031 & 0.127 & 0.150 & -0.236 \\
\hline steel & 0.014 & 0.084 & 0.133 & 0.199 & 0.175 & 0.014 & 0.071 & 0.156 & 0.288 \\
\hline telcm & 0.198 & 0.006 & -0.095 & -0.005 & -0.054 & -0.153 & -0.275 & -0.292 & -0.216 \\
\hline toys & -0.276 & 0.144 & 0.067 & -0.091 & 0.005 & 0.060 & -0.026 & -0.121 & -0.221 \\
\hline $\operatorname{trans}$ & 0.404 & 0.430 & 0.437 & 0.467 & 0.321 & 0.185 & 0.161 & 0.120 & 0.240 \\
\hline txtls & 0.121 & 0.090 & 0.130 & 0.123 & 0.084 & 0.093 & -0.001 & -0.079 & 0.003 \\
\hline util & -0.350 & -0.325 & -0.100 & -0.121 & -0.179 & -0.115 & -0.217 & -0.260 & -0.149 \\
\hline whlsl & 0.088 & 0.293 & 0.236 & 0.186 & 0.063 & 0.013 & -0.160 & -0.103 & -0.252 \\
\hline
\end{tabular}


Table 17. Quantile cross-autocorrelation coefficients $\beta_{2}(\tau)$ estimates of $r_{t}^{\text {ind }}=\beta_{0}(\tau)+\beta_{1}(\tau) r_{t-1}^{\text {ind }}+\beta_{2}(\tau) r_{t-1}^{\text {banks }}+\varepsilon_{t}^{\text {ind }}$ based on 79 monthly returns over the period from August 2010 to February 2017. Significant cross-autocorrelations are indicated in boldface for significance levels of $10 \%$ or lower

\begin{tabular}{|c|c|c|c|c|c|c|c|c|c|}
\hline$\tau$ & 0.1 & 0.2 & 0.3 & 0.4 & 0.5 & 0.6 & 0.7 & 0.8 & 0.9 \\
\hline aero & 0.383 & 0.059 & -0.069 & -0.107 & -0.195 & -0.199 & -0.257 & -0.351 & -0.315 \\
\hline agric & 0.261 & 0.275 & 0.125 & 0.204 & 0.088 & 0.030 & 0.112 & -0.020 & 0.075 \\
\hline autos & 0.590 & -0.304 & -0.216 & -0.177 & -0.332 & -0.648 & -0.639 & -0.694 & -0.547 \\
\hline beer & 0.079 & 0.006 & -0.091 & -0.086 & -0.102 & -0.120 & -0.141 & -0.158 & -0.058 \\
\hline bldmt & 0.246 & 0.117 & -0.074 & -0.183 & -0.107 & -0.136 & -0.132 & -0.136 & -0.338 \\
\hline books & 0.200 & 0.213 & 0.156 & 0.139 & 0.048 & -0.159 & -0.117 & -0.157 & -0.290 \\
\hline boxes & 0.437 & 0.208 & -0.001 & -0.056 & 0.163 & -0.095 & -0.076 & -0.233 & -0.303 \\
\hline bussv & 0.308 & 0.121 & 0.112 & -0.046 & -0.158 & -0.254 & -0.302 & -0.184 & -0.408 \\
\hline chems & 0.051 & -0.299 & -0.223 & -0.388 & -0.367 & -0.248 & -0.248 & -0.271 & -0.396 \\
\hline chips & -0.323 & -0.049 & -0.070 & -0.221 & -0.024 & -0.238 & -0.276 & -0.262 & -0.339 \\
\hline clths & 0.074 & -0.119 & -0.243 & -0.144 & -0.142 & -0.194 & -0.306 & -0.488 & -0.663 \\
\hline cnstr & 0.495 & 0.268 & 0.090 & 0.114 & 0.106 & -0.118 & -0.241 & -0.357 & -0.186 \\
\hline coal & 0.464 & 0.058 & -0.049 & 0.271 & -0.038 & -0.247 & -0.586 & -0.509 & -1.108 \\
\hline comps & -0.100 & 0.039 & -0.139 & -0.203 & -0.257 & -0.204 & -0.311 & $-\mathbf{- 0 . 3 8 4}$ & -0.378 \\
\hline gs & 0.201 & 0.170 & 0.094 & -0.036 & $-\mathbf{0 . 1 8 3}$ & -0.174 & -0.244 & $-\mathbf{- 0 . 1 9 9}$ & -0.278 \\
\hline elceq & 0.495 & 0.325 & -0.101 & -0.184 & -0.187 & -0.279 & -0.236 & -0.209 & -0.306 \\
\hline fabpr & 0.482 & 0.595 & 0.310 & 0.047 & -0.230 & -0.255 & -0.366 & -0.422 & -0.658 \\
\hline fin & -0.303 & -0.352 & -0.183 & -0.140 & -0.139 & -0.180 & -0.087 & -0.010 & 0.399 \\
\hline food & -0.078 & -0.031 & 0.073 & 0.073 & 0.012 & -0.014 & 0.031 & 0.002 & 0.097 \\
\hline fun & 0.401 & 0.058 & -0.196 & -0.286 & -0.378 & -0.133 & -0.211 & -0.370 & -0.446 \\
\hline gold & -0.427 & -0.472 & -0.341 & -0.643 & -0.619 & -0.502 & -0.627 & -0.432 & -0.781 \\
\hline guns & -0.187 & 0.025 & 0.027 & -0.102 & -0.097 & -0.034 & -0.172 & -0.081 & 0.098 \\
\hline th & 0.301 & 0.152 & -0.023 & -0.085 & -0.096 & -0.164 & -0.241 & $\mathbf{- 0 . 4 8 9}$ & -0.538 \\
\hline hshld & 0.069 & -0.125 & -0.070 & -0.026 & -0.091 & -0.083 & -0.112 & -0.080 & 0.112 \\
\hline insur & -0.143 & 0.037 & 0.154 & 0.122 & 0.200 & 0.187 & 0.227 & -0.079 & 0.107 \\
\hline labeq & 0.045 & -0.230 & -0.246 & -0.182 & -0.247 & -0.149 & -0.146 & -0.292 & -0.306 \\
\hline mach & 0.548 & 0.219 & -0.003 & -0.230 & -0.319 & -0.468 & -0.330 & -0.173 & -0.199 \\
\hline meals & -0.010 & -0.152 & -0.143 & -0.210 & -0.141 & -0.247 & -0.277 & -0.231 & -0.18 \\
\hline medeq & 0.256 & 0.223 & 0.011 & -0.021 & -0.188 & -0.194 & -0.169 & -0.080 & 0.002 \\
\hline mines & -0.004 & -0.090 & -0.138 & -0.327 & -0.495 & -0.345 & -0.400 & $\mathbf{- 0 . 6 7 7}$ & -0.733 \\
\hline oil & -0.010 & 78 & 1 & -0.084 & -0 & -0 & 23 & -0.322 & -0.325 \\
\hline other & 0.056 & 4 & -0. & -0.030 & -0 . & -0 . & -0.168 & -0.136 & -0.148 \\
\hline paper & 0.515 & -0.036 & -0.254 & -0.142 & -0.065 & -0.100 & -0.123 & -0.146 & -0.278 \\
\hline persv & 0.500 & -0.003 & -0.214 & -0.323 & -0.343 & -0.097 & -0.175 & -0.127 & 0.066 \\
\hline rlest & 0.396 & -0.030 & 0.109 & -0.083 & -0.393 & -0.286 & -0.007 & -0.123 & -0.092 \\
\hline rtail & 0.243 & 0.069 & 0.023 & -0.027 & -0.194 & -0.290 & -0.213 & -0.239 & -0.213 \\
\hline rubbr & $\mathbf{0 . 5 7 2}$ & 0.327 & -0.065 & 0.092 & -0.025 & -0.190 & -0.221 & -0.201 & -0.153 \\
\hline ships & 0.553 & 0.313 & -0.056 & -0.089 & -0.272 & -0.296 & $-\mathbf{0 . 5 8 0}$ & $-\mathbf{- 0 . 8 2 5}$ & -0.620 \\
\hline smoke & -0.191 & -0.262 & -0.166 & -0.107 & -0.254 & -0.168 & -0.064 & -0.014 & 0.082 \\
\hline soda & -0.132 & -0.038 & 0.023 & -0.056 & -0.051 & -0.025 & 0.000 & -0.075 & -0.045 \\
\hline steel & 0.571 & 0.153 & -0.103 & -0.442 & -0.576 & -0.410 & -0.617 & -0.645 & -0.674 \\
\hline telcm & 0.024 & -0.045 & 0.089 & -0.045 & -0.101 & -0.111 & -0.076 & -0.142 & -0.124 \\
\hline toys & 0.098 & -0.228 & -0.305 & -0.206 & -0.355 & -0.271 & -0.337 & -0.371 & -0.450 \\
\hline trans & 0.014 & -0.344 & -0.364 & -0.527 & -0.359 & -0.359 & $-\mathbf{0 . 3 5 0}$ & $-\mathbf{- 0 . 3 6 9}$ & -0.504 \\
\hline txtls & 0.135 & 0.088 & -0.143 & -0.159 & -0.281 & -0.306 & $-\mathbf{0 . 4 0 1}$ & $-\mathbf{- 0 . 4 4 9}$ & -0.452 \\
\hline util & 0.072 & -0.007 & 0.047 & 0.073 & 0.029 & -0.021 & -0.042 & -0.068 & -0.131 \\
\hline whlsl & 0.348 & 0.047 & -0.065 & -0.135 & -0.220 & -0.143 & -0.097 & -0.113 & -0.141 \\
\hline
\end{tabular}


Table 18. Quantile regression cross- and autocorrelation coefficient estimates of the model $r_{t}^{\text {factor }}=\beta_{0}(\tau)+\beta_{1}(\tau) r_{t-1}^{\text {factor }}+\beta_{2}(\tau) r_{t-1}^{\text {banks }}+\varepsilon_{t}^{\text {factor }}$. Based on 79 monthly returns over the period August 2010 to February 2017. Significant correlations are indicated in boldface for significance levels of $10 \%$ or lower.

\begin{tabular}{lrrrrrrrrr}
\hline \multicolumn{1}{c}{$\tau$} & 0.1 & 0.2 & 0.3 & 0.4 & 0.5 & 0.6 & 0.7 & 0.8 & 0.9 \\
\hline Autocorrelation & & & & & & & & & \\
market & -0.143 & 0.170 & 0.178 & -0.005 & -0.057 & -0.126 & -0.283 & -0.331 & -0.282 \\
size & -0.182 & -0.241 & -0.327 & -0.181 & -0.221 & -0.072 & -0.151 & $-\mathbf{0 . 3 3 3}$ & $\mathbf{- 0 . 3 2 8}$ \\
value & 0.194 & 0.203 & 0.215 & $\mathbf{0 . 2 6 8}$ & $\mathbf{0 . 2 9 3}$ & 0.214 & 0.146 & -0.026 & -0.080 \\
momentum & 0.131 & -0.039 & -0.015 & 0.016 & 0.047 & -0.113 & 0.019 & 0.069 & 0.032 \\
investment & 0.151 & 0.150 & 0.166 & 0.182 & 0.146 & 0.162 & 0.120 & 0.157 & 0.204 \\
profitability & -0.247 & -0.151 & -0.021 & 0.071 & 0.026 & -0.010 & -0.073 & 0.239 & $\mathbf{0 . 3 7 0}$ \\
& & & & & & & & & \\
Cross- & & & & & & & & & \\
autocorrelation & & & & & & & & & \\
market & 0.440 & -0.009 & -0.118 & -0.062 & -0.094 & -0.121 & -0.049 & -0.073 & -0.215 \\
size & 0.101 & 0.147 & 0.044 & -0.040 & 0.007 & -0.011 & 0.008 & -0.014 & -0.004 \\
value & -0.026 & -0.058 & -0.011 & 0.016 & 0.002 & -0.001 & 0.039 & $\mathbf{0 . 1 4 8}$ & $\mathbf{0 . 1 5 6}$ \\
momentum & 0.141 & 0.126 & 0.132 & 0.082 & 0.115 & 0.085 & 0.040 & 0.108 & 0.059 \\
investment & -0.045 & 0.019 & 0.053 & 0.043 & 0.027 & -0.001 & 0.027 & 0.038 & -0.027 \\
profitability & $\mathbf{0 . 1 0 0}$ & -0.045 & -0.016 & -0.018 & -0.093 & -0.101 & -0.070 & -0.042 & -0.039 \\
\hline
\end{tabular}




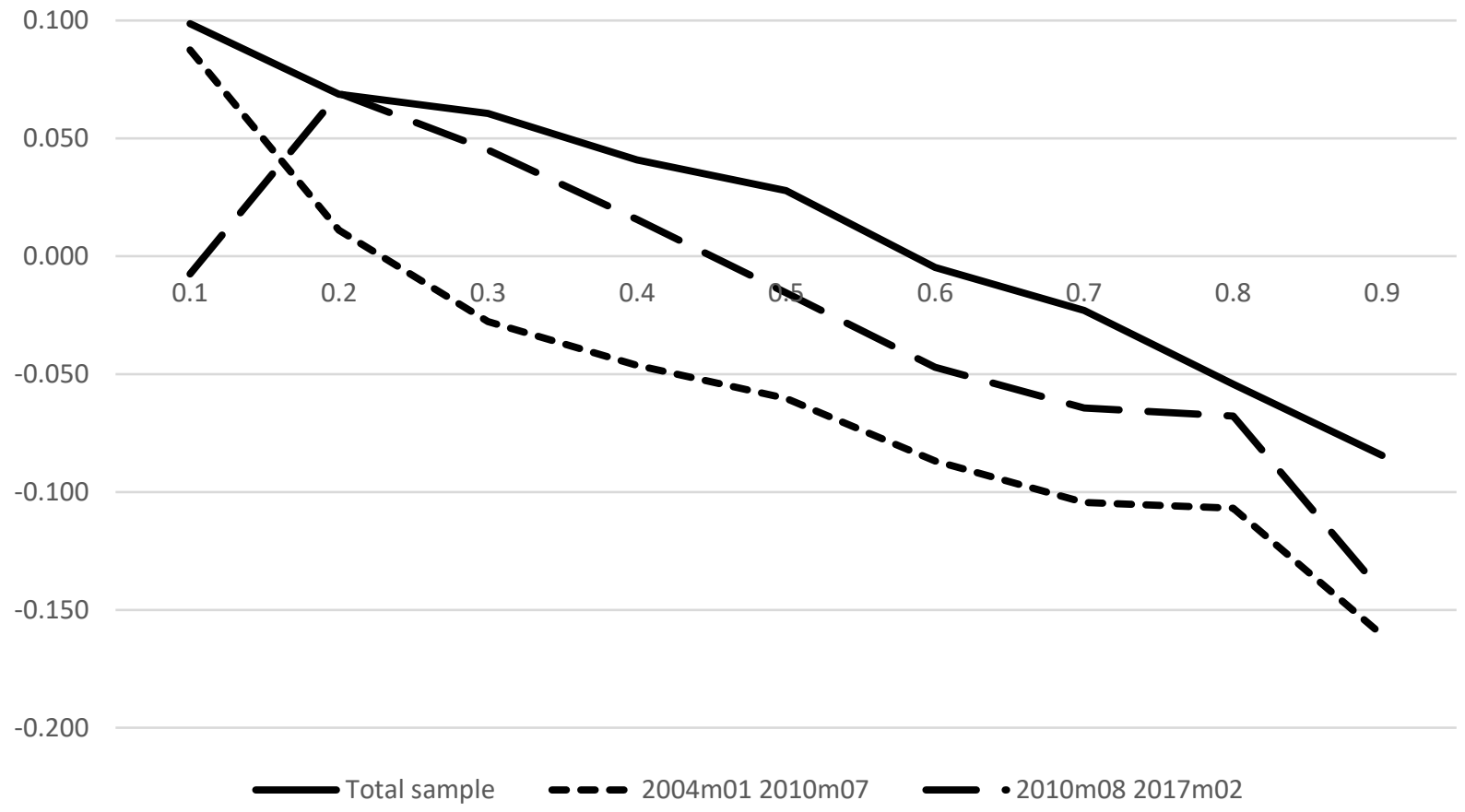

Figure 1. Average autocorrelation coefficient $\beta_{1}(\tau)$ over the 47 industry portfolios from the quantile regressions $r_{t}^{\text {ind }}=\beta_{0}(\tau)+\beta_{1}(\tau) r_{t-1}^{\text {ind }}+\beta_{2}(\tau) r_{t-1}^{\text {banks }}+\varepsilon_{t}^{\text {ind }}$ for the total sample period and for the two subsample periods. 


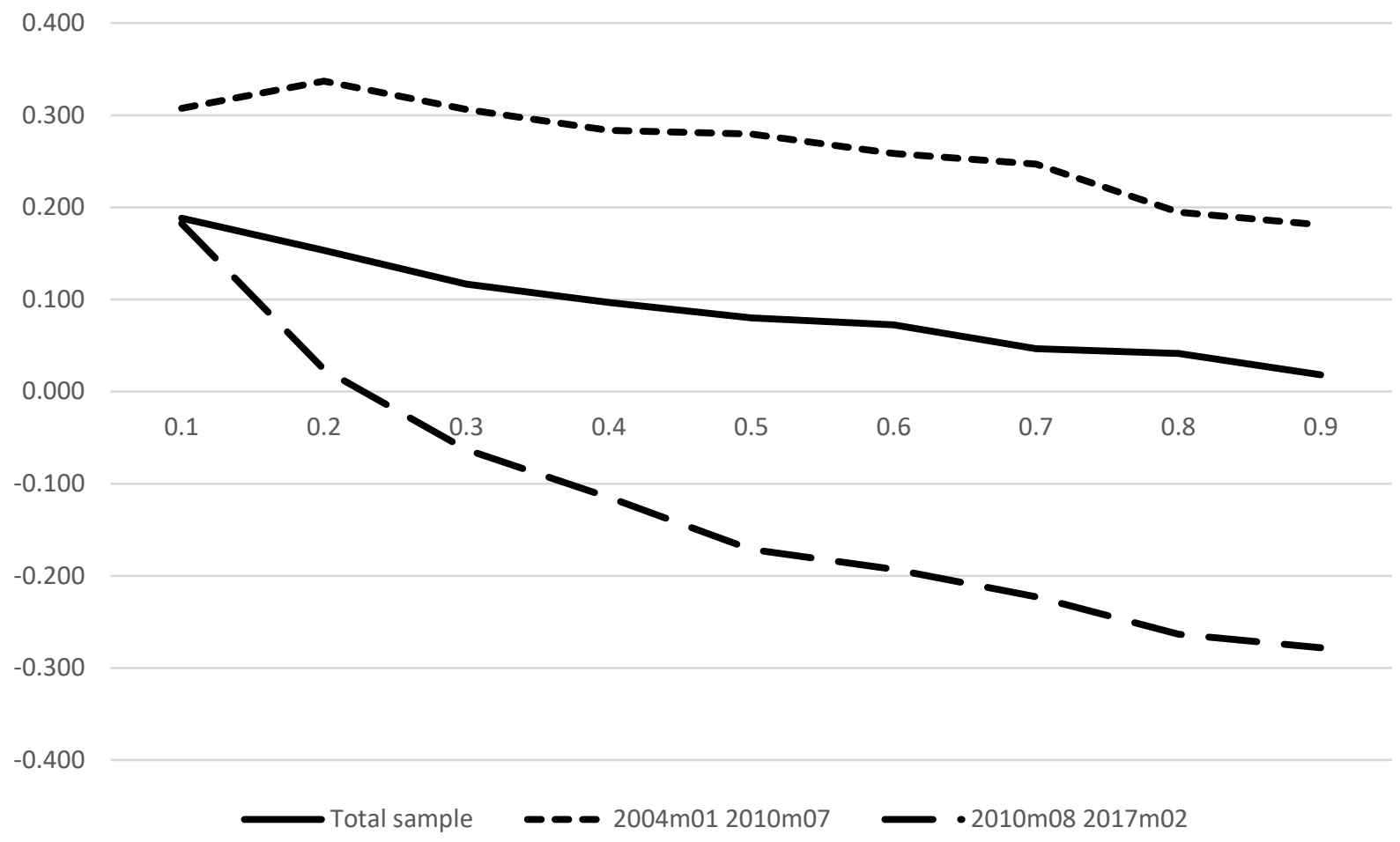

Figure 2. Average cross-autocorrelation coefficient $\beta_{2}(\tau)$ over the 47 industry portfolios from the quantile regressions $r_{t}^{\text {ind }}=\beta_{0}(\tau)+\beta_{1}(\tau) r_{t-1}^{\text {ind }}+\beta_{2}(\tau) r_{t-1}^{\text {banks }}+\varepsilon_{t}^{\text {ind }}$ for the total sample period and for the two subsample periods. 


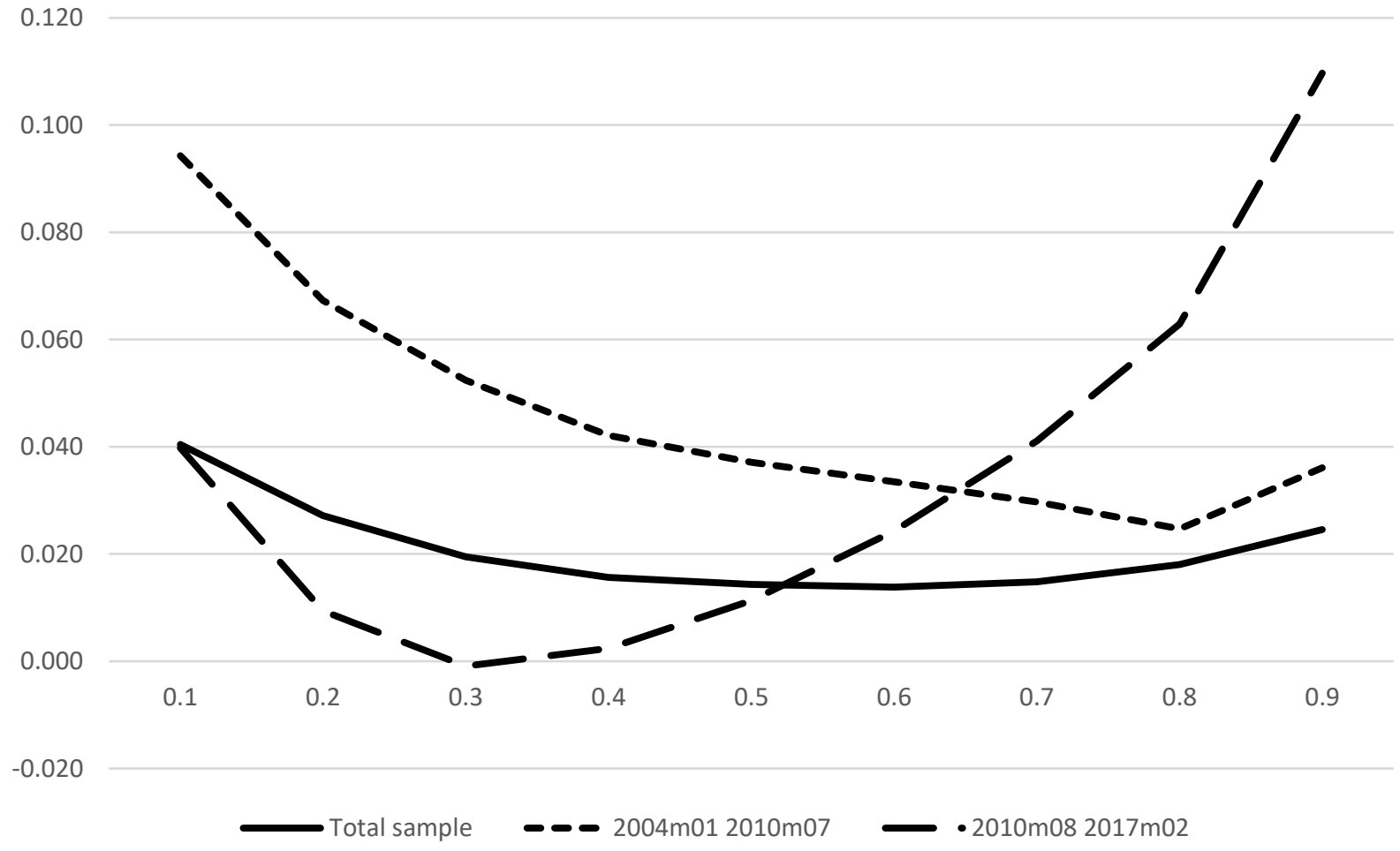

Figure 3. Average adjusted R-squares over the 47 industry portfolios from the quantile regressions $r_{t}^{\text {ind }}=\beta_{0}(\tau)+\beta_{1}(\tau) r_{t-1}^{\text {ind }}+\beta_{2}(\tau) r_{t-1}^{\text {banks }}+\varepsilon_{t}^{\text {ind }}$ for the total sample period and for the two subsample periods. 


\section{Appendix A}

List of the included industry portfolios with abbreviations used in the text

Aircraft (aero)

Agriculture (agric)

Automobiles and Trucks (autos)

Banking (banks)

Beer \& Liquor (beer)

Construction Materials (bldmt)

Printing and Publishing (books)

Shipping Containers (boxes)

Business Services (bussv)

Chemicals (chems)

Electronic Equipment (chips)

Apparel (clths)

Construction (cnstr)

Coal (coal)

Computers (comps)

Pharmaceutical Products (drugs)

Electrical Equipment (elceq)

Fabricated Products (fabpr)

Financial Trading (fin)

Food Products (food)

Entertainment (fun)

Precious Metals (gold)

Defense (guns)

Healthcare (hlth)

Consumer Goods (hshld)

Insurance (insur)

Measuring and Control Equipment (labeq)

Machinery (Mach)

Restaurants, Hotels, Motels (meals)

Medical Equipment (medeq)

Non-Metallic and Industrial Metal Mining (mines)

Petroleum and Natural Gas (oil)

Almost Nothing (other)

Business Supplies (paper)

Personal Services (persv)

Real Estate (rlest)

Retail (rtail)

Rubber and Plastic Products (rubbr)

Shipbuilding, Railroad Equipment (ships)

Tobacco Products (smoke)

Candy \& Soda (soda)

Steel Works Etc (steel)

Communication (telcm)

Recreation (toys)

Transportation (trans)

Textiles (txtls)

Utilities (util)

Wholesale (whlsl)

Source: http://mba.tuck.dartmouth.edu/pages/faculty/ken.french/Data_Library/changes_ind.html 